\title{
Machining Elimination through Application of Thread Forming Fasteners in Net-Shaped Cast Holes
}

Final Report United States Council for Automotive Research LLC (USCAR) Project No.: FAS 1005 DOE award number: DE-EE0003482

\author{
Ryan Cleaver \\ Tech Knowledge \\ Todd Cleaver \\ Tech Knowledge \\ Richard Talbott \\ Ford Motor Company
}

March 13, 2012 


\section{Project Title:}

Machining Elimination through Application of Thread Forming Fasteners in

Net-Shaped Cast Holes

\section{Final Scientific/Technical Report}

DOE award number: DE-EE0003482

Issue Date: March 13, 2012

Project Period: 8/16/2010 - 3/31/2012

Recipient: The United States Council for Automotive Research LLC (USCAR)

1000 Town Center Drive

Suite 300

Southfield, MI 48075

Telephone: 248-223-9000

\section{Project Director:}

William Charron

Ford Motor Company

Telephone: (313) 805-6628

E-Mail:wcharron@ford.com

\section{Principle Investigator:}

Todd Cleaver

Tech Knowledge

Telephone: (734) 675-5562

E-Mail: Todd@TechKnowledgeAMD.com

\section{Project Participants:}

The United States Council for Automotive Research LLC (USCAR), the collaborative research organization for Chrysler Group LLC, Ford and General Motors Corporation

Acument

ATF

REMINC 


\section{Acknowledgment:}

This report is based upon work supported by the U. S. Department of Energy under Award No.: DE-EE0003482.

\section{Disclaimer:}

Any findings, opinions, and conclusions or recommendations expressed in this report are those of the author and do not necessarily reflect the views of the Department of Energy

\section{Proprietary Data Notice:}

Nothing in this report is considered proprietary.

\section{Document Availability:}

Reports are available free via the U.S. Department of Energy (DOE) Information Bridge Website: http://www.osti.gov/bridge

Reports are available to DOE employees, DOE contractors, Energy Technology Data Exchange (ETDE) representatives, and Informational Nuclear Information System (INIS) representatives from the following source:

Office of Scientific and Technical Information

P.O. Box 62

Oak Ridge, TN 37831

Tel: (865) 576-8401

FAX: (865) 576-5728

E-mail: reports@osti.gov

Website: http://www.osti.gov/contract.html 


\section{Contents}

1.0 List of Acronyms........................................................... 5

2.0 Lists of Figures.............................................................. 6

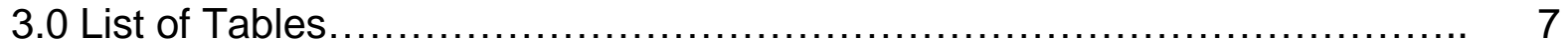

4.0 List of Appendices.......................................................... 8

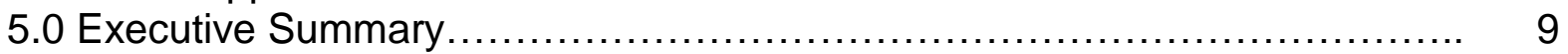

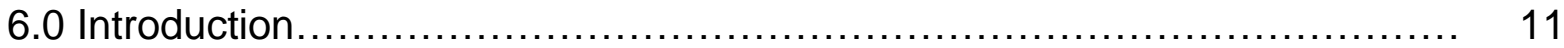

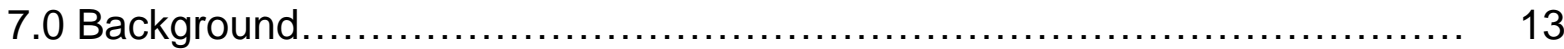

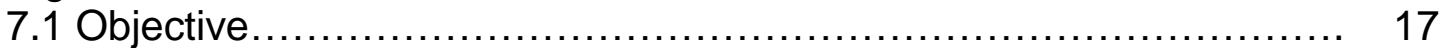

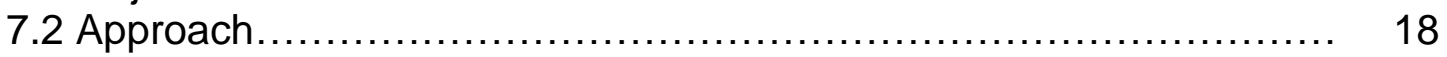

7.3 Qualifications and Resources.................................... 21

8.0 Results and Discussion.................................................... 23

8.1 Aluminum Castings.................................................... 23

8.1A Fasteners Straight Out of the Box........................... 23

8.1B Dry and Lubricated Fasteners............................... 25

8.1C Robustness Testing ....................................... 26

8.2 Magnesium Castings ............................................. 28

8.2A Fasteners Straight Out of the Box......................... 28

8.2B Dry and Lubricated Fasteners............................. $\quad 30$

8.2C Robustness Testing.......................................... 31

8.3 Discussion.......................................................... 33

9.0 Benefits Assessment ........................................................ 35

9.1 Advantages over Traditional Threaded Fasteners..................... 35

9.2 Automotive Applications............................................ 36

9.2A Potential Energy Benefits .................................. 36

9.2B Potential Economic Benefits............................. 37

9.2C Potential Environmental Benefits......................... 37

9.3 Non-Automotive Applications...................................... 38

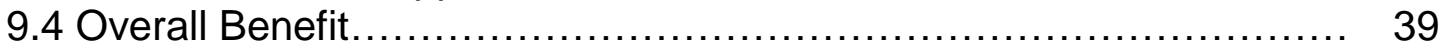

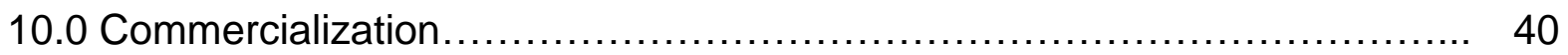

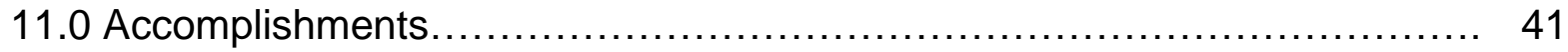

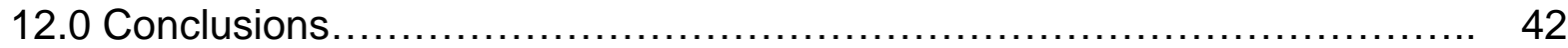

13.0 Recommendations......................................................... 43

14.0 References and/or Bibliography ...................................... 44

15.0 Appendices.................................................................... 45

15.1 Team Members.................................................. 45

15.2 Size \& Shape Hole Dimensions for TAPTITES in Aluminum........... 46

15.3 Size \& Shape Hole Dimensions for ALtracs in Magnesium............. 48

15.4 Cross-Section Metallographic Samples.............................. 50 


\subsection{List of Acronyms}

$\begin{array}{ll}\text { AFS } & \text { American Foundry Society } \\ \text { Btu } & \text { British thermal unit } \\ \text { Deg. } & \text { Degree } \\ \text { DOE } & \text { Department of Energy } \\ \text { HVAC } & \text { Heating, ventilation, and air conditioning } \\ \text { KN } & \text { Kilonewton } \\ \text { Max. } & \text { Maximum } \\ \text { Min. } & \text { Minimum } \\ \text { Mm } & \text { Millimeter } \\ \text { Mmbtu } & \text { Million british thermal units } \\ \text { NADCA } & \text { North American Die Casting Association } \\ \text { Nom } & \text { Nominal } \\ \text { Nm } & \text { Newton meter } \\ \text { RPM } & \text { Revolutions per minute } \\ \text { PNNL } & \text { Pacific Northwest National Laboratory } \\ \text { STD DEV } & \text { Standard deviation } \\ \text { TFF } & \text { Thread forming fastener } \\ \text { X-3STD } & \text { Target minus 3 standard deviations } \\ \text { X+3STD } & \text { Target plus 3 standard deviations } \\ \text { USAMP } & \text { United States Automotive Materials Partnership } \\ \text { USCAR } & \text { United States Council for Automotive Research }\end{array}$




\subsection{List of Figures}

$\underline{\text { Page }}$

Fig. 7.1 Thread Forming Fastener........................................... 13

Fig. 7.2 Current vs. New Bolted Assembly Process........................... 14

Fig. 7.3 Clamp Load and Input Torque Plot for a Typical Machine Screw...... 16

Fig. 7.4 Clamp Load and Input Torque Plot for a Typical Thread Forming

Fastener.......................................................... 17

Fig. 7.5 Die with 12 Bosses and 12 Nuts........................................ 19

Fig. 7.6 Thread Forming Fastener and Cast Nut............................ 19

Fig. 7.7 Ford Fastener Laboratory Clamp Load Test Cell...................... 20

Fig. 7.8 Load Cell with Thread Forming Fastener being Driven into Cast Nut... 20

Fig. 15.1 Boss Designations for Cast Nuts in Aluminum....................... 46

Fig. 15.2 Boss Designations for Cast Nuts in Magnesium..................... 48

Fig. 15.3 Cross-Section Metallographic Sample of M6 Taptite Thread Forming Fastener at $15 \mathrm{~mm}$ Depth in 0.5을 Draft Angle As-Cast Hole in A380

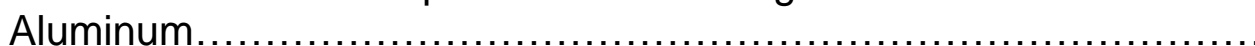

Fig. 15.4 Cross-Section Metallographic Sample of M6 ALtracs Thread Forming Fastener at $18 \mathrm{~mm}$ Depth in 0.5 Draft Angle As-Cast Hole in AZ91D Magnesium. 


\subsection{List of Tables}

Page

Table 7.1 Cast Hole Size Variation

Table 8.1 Data Recorded for Full Range of Cast Hole Size Variation, Straight Out of the Box in Aluminum....

Table 8.2 Data Recorded for Full Range of Cast Hole Size Variation, Dry and Lubed in Aluminum....

Table 8.3 Data Recorded for Robustness Range of Cast Hole Size Variation in Aluminum

Table 8.4 Data Recorded for Full Range of Cast Hole Size Variation, Straight Out of the Box in Magnesium

Table 8.5 Data Recorded for Full Range of Cast Hole Size Variation, Dry and Lubed in Magnesium.

Table 8.6 Data Recorded for Robustness Range of Cast Hole Size Variation in Magnesium.

Table 8.7 Summary of Clamp Load Variation Results.

Table 9.1 Estimated Energy and Economic benefits for Non-Automotive Applications

Table 15.1 Hole Dimensions and Draft Angles for Cast Nuts in Aluminum. 


\subsection{List of Appendices}

Page

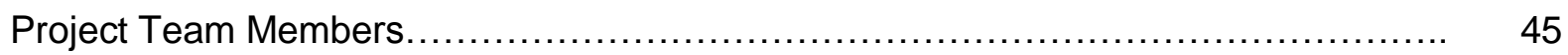

Size \& Shape Hole Dimensions for TAPTITES in Aluminum ........................ 46

Size \& Shape Hole Dimensions for ALtracs in Magnesium.......................... 48

Cross-Section Metallographic Samples........................................ 50 


\subsection{Executive Summary}

By definition, a thread forming fastener is one that generates an internal thread through material displacement. Thread forming fasteners generally have a lobular end, trilobular being the most common, to create pressure points for forming the material as the fastener is driven into the hole.

Progress has been made in applying thread forming fasteners into machined or stamped holes featured in steel automotive applications for general assembly. Use of these fasteners has eliminated the tapping operation, which reduced costs, investment, and improved warranty, while delivering better joint properties within an assembly. By using thread forming fasteners with net-shaped holes in lightweight castings, the drilling operation and associated equipment investment is also eliminated without sacrificing joint performance.

The ultimate objective of this work was to eliminate approximately $30 \%$ of the machining performed in typical automotive engine and transmission plants by using thread forming fasteners in as-cast holes of aluminum and magnesium cast components.

There are significant hurdles to be overcome to appreciate this opportunity. Whereas thread forming fastener technology is well understood for drilled holes in mild steel applications, it is not for aluminum castings, today's primary power train material and even less understood for magnesium castings, tomorrow's material of choice. The primary issues at the source of engineers' reluctance to implementing thread forming fasteners in lightweight castings are:

- Little proof of consistency of clamp load vs. input torque in either aluminum or magnesium castings.

- No known data to understand the effect on consistency of clamp load as casting dies wear.

The clamp load consistency concern is founded in the fact that a portion of the input torque used to create clamp load is also used to create threads. The torque used for thread forming may not be consistent due to variations in casting material, hole size and shape due to tooling wear and process variation (thermal and mechanical). There is little data available to understand the magnitude of this concern or to form the basis of potential solutions if the range of clamp load variation is very high $(>+/-30 \%)$.

The range of variation that can be expected in as-cast hole size and shape over the full life cycle of a high pressure die casting die was established in previous work completed by Pacific Northwest National Laboratory, (PNNL). This established range of variation was captured in a set of 12 cast bosses by designing core pins at the size and draft angles identified in the sited previous work. The cast bosses were cut into "nuts" that could be used in the Ford Fastener Laboratory test-cell to measure clamp load when a thread forming fastener was driven into a cast nut. 
There were two sets of experiments run. First, a series of cast aluminum nuts were made reflecting the range of shape and size variations to be expected over the life cycle of a die casting die. Taptite thread forming fasteners, (a widely used thread forming fastener suitable for aluminum applications), were driven into the various cored, as-cast nuts at a constant input torque and resulting clamp loads were recorded continuously. The clamp load data was used to determine the range of clamp loads to be expected. The bolts were driven to failure. The clamp load corresponding to the target input of $18.5 \mathrm{Nm}$ was recorded for each fastener.

In a like fashion, a second set of experiments were run with cast magnesium nuts and ALtracs thread forming fasteners, (a widely used thread forming fastener suitable for magnesium applications). Again all clamp loads were recorded and analyzed similarly to the Taptites in aluminum cast nuts.

Results from previous work performed on the same test cell for a Battelle project using standard M8 bolts into standard M8 nuts were included as a comparator for a standard bolt and nut application.

The results for the thread forming fasteners in aluminum cast holes were well within industry expectations of $+/-30 \%$ for out of the box and robustness range testing. The results for the dry and lubed extreme conditions were only slightly higher than industry expectations at $+/-35.6 \%$. However, when compared to the actual Battelle results $(+/-$ $40 \%$ ) for a standard bolt and nut the tread forming fasteners performed slightly better.

The results for the thread forming fasteners in magnesium cast holes were all well within industry expectations of $+/-30 \%$ for all three conditions.

The robustness range $(.05 \mathrm{~mm}$ larger and smaller holes than the expected wear pattern of a die casting die at full life cycle) results also fell within the industry expectations for standard threaded fasteners. These results were very encouraging.

It was concluded that this work showed that clamp load variation with thread forming fasteners is consistent with industry expectations for standard steel bolts and nuts at +/$30 \%$. There does not appear to be any significant increase in clamp load variation due to the application of thread forming fasteners in as-cast holes of aluminum or magnesium over the effective life of a die casting mold.

The fully implemented potential benefit of thread forming fasteners in as-cast holes of aluminum and magnesium is estimated to be 6 trillion Btu per year for North America. Economic benefit is estimated to be nearly $\$ 800$ million per year. Environmental benefits and quality improvements will also result from full implementation of this technology.

This report will be distributed to the domestic automobile companies as well as the associated supply base. In addition, the report will be distributed to the fastener and casting industry associations. 


\subsection{Introduction}

The ultimate objective of the work performed was to eliminate approximately $30 \%$ of the machining performed in typical automotive engine and transmission plants by using thread forming fasteners in as-cast holes of aluminum and magnesium cast components.

There are significant hurdles to be overcome to appreciate this opportunity. Whereas thread forming fastener technology is well understood for drilled holes in mild steel applications, it is not for aluminum castings, today's primary power train material and even less understood for magnesium castings, tomorrow's material of choice. The primary issues at the source of engineers' reluctance to implementing thread forming fasteners in lightweight castings are:

- Little proof of consistency of clamp load vs. input torque in either aluminum or magnesium castings.

- No known data to understand the effect on consistency of clamp load as casting dies wear.

The clamp load data gathered in this project will determine the severity of clamp load variation in as-cast holes. This range of variation will be compared to clamp load variation from traditional bolt and nut clamp load variation. The comparison will either help overcome the reluctance of engineers to use thread forming fasters or result in identification of additional work to create methods and strategies for tightening the range.

Progress has been made in applying thread forming fasteners into machined or stamped holes featured in steel automotive applications for general assembly. Use of these fasteners has eliminated the tapping operation, which reduced costs, investment, and improved warranty, while delivering better joint properties within an assembly. By using thread forming fasteners with net-shaped holes in lightweight castings, the drilling operation and associated equipment investment is also eliminated without sacrificing joint performance.

Potential applications for using thread forming fasteners in cast components are numerous and include powertrain (transmissions, engines, and rear axles), chassis, (control arms, suspensions), body structures that utilize large castings (inner doors, lift gates, under-hood attachments and supports), and interior assemblies (instrument panels, steering columns, seat structures and accessories). Progress in applying the concept to aluminum castings has been minimal, and even less with magnesium. Automotive studies indicate that at least $30 \%$ of all machining energy usage in a typical powertrain plant is drilling and tapping of holes for threaded fasteners. 
Ultimately, 5 trillion btu/year of energy savings appears feasible as a result of full implementation of this technology in the North American automobile industry. This number is higher when you add in heavy trucks, farm equipment, military, marine, heavy construction equipment, gardening equipment, recreational vehicles, and aero/space.

The estimated economic benefit to the automobile industry at full implementation is over $\$ 600$ million.

Commercialization of the technology will be assured by the involvement of fastener manufacturers and the industrial associations: Industrial Fasteners Institute (IFI), North American Die Casting Association (NADCA), and American Foundry Society (AFS). 


\subsection{Background}

By definition, a thread forming fastener is one that generates an internal thread through material displacement rather than material removal. Thread forming fasteners generally have a lobular end, tri-lobular being the most common, to create pressure points for forming the material as the fastener is driven into the hole.
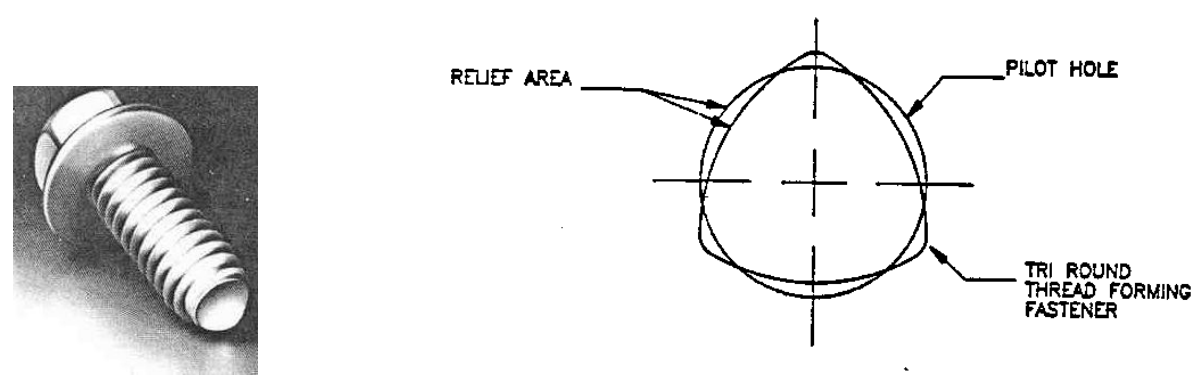

Fig. 7.1 Thread Forming Fastener

Many thread forming fasteners create a standard or near standard thread in the hole such that they can be replaced by a standard thread, traditional bolt during service to the component later in the product life.

There are several advantages to the manufacturer in application of thread forming fasteners, especially if the fasteners can be applied directly to as-cast holes. The most significant is the elimination of several expensive, capital intensive machining operations. The current methods require a drilling operation followed by a probing station to assure a complete, unobstructed hole has been accomplished. This is followed by a tapping operation and cleaning process to assure all debris resulting from the previous cutting steps has been removed from the hole. Gaging is required throughout. In addition, a very significant coolant and chip removal system is required throughout. All of these steps are not required if this new technology is fully developed and the equivalent clamp load can be achieved. 

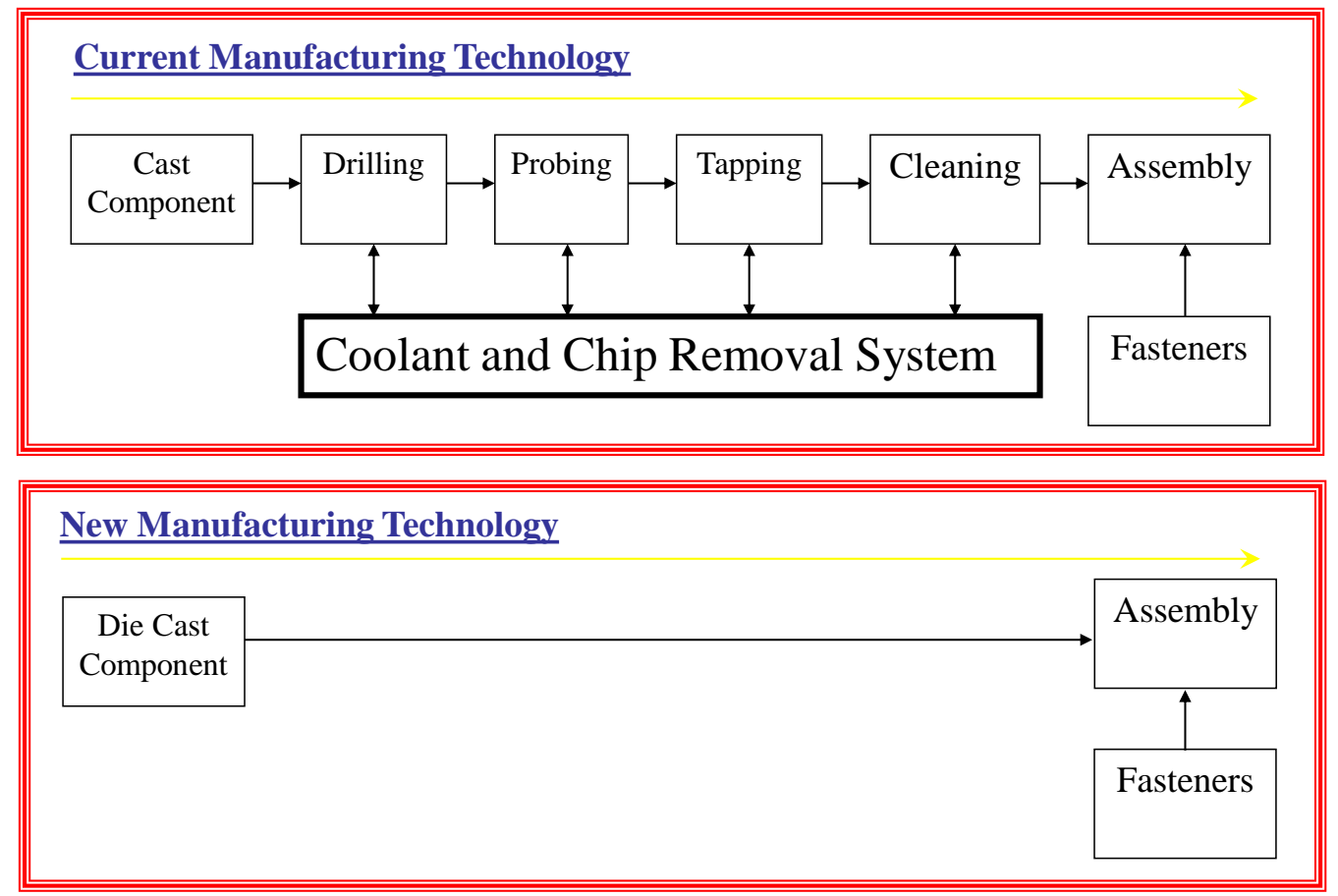

Fig. 7.2 Current vs. New Bolted Assembly Process

Automotive studies indicate that at least $30 \%$ of all machining energy in a typical powertrain (engine or transmission) plant is consumed in the drilling and tapping of holes for fasteners. Studies also indicate operating cost savings of $\$ .07$ to $\$ .09$ per fastener.

There are several additional advantages to be considered:

- Cross threading is not possible resulting in higher productivity, improved quality, less warranty concerns

- Stronger internal threads due to the cold flow work hardening during thread formation

- Elimination of chip handling and reprocessing

- Elimination of fastener locking features like lock washers due to the superior vibration resistance of the lobular design, also resulting in less warranty calls for squeaks and rattles

- Environmental improvement due to elimination of machining coolant

- Enabler to lightweight material substitution (CAFÉ improvement) through reduction in cost differential between lightweight materials (Al. and Mg.) and ferrous materials.

In spite of the successful integration of thread forming fasteners into drilled holes in steel, there have been several perceived inhibitors to implementation of thread forming fasteners into as-cast light metals. The most significant inhibitors are (were): 
- Casting variation over the life of the die such as cast hole size, shape and location

- Added casting costs to maintain casting hole size, shape and location

- Debris resulting from thread forming

- Reusability of the hole and thread forming fastener for service requirements

- Consistency of clamp load when relying on input torque as the control

- Corrosion issues with steel fasteners in magnesium casting applications

Many of these inhibitors were overcome by recent work, (see References: USAMP/DOE Project AMD 407), completed at Pacific Northwest National Laboratory (PNNL). That work showed thread forming fasteners will perform successfully over the full range of casting hole variation over the full life of the die without any special service or cost to the caster. The same effort showed that the thread forming fasteners and threaded holes would function successfully over a wide range of reuses for service. Finally, the PNNL work indicated that more debris was generated with thread forming fasteners in as-cast holes vs. traditional fasteners in drilled and tapped holes, but only in throughhole applications where debris is not important because they are generally external to the assembly. Blind-hole applications resulted in no measurable difference in debris generation.

The remaining inhibitors, clamp load consistency and corrosion with magnesium remain. Corrosion in applications of steel fasteners in magnesium castings is not unique to thread forming fasteners applications. Isolation and coating techniques used with steel bolts in traditional drilled and tapped magnesium casting holes can apply or be modified to deal with the corrosion issue that may occur in thread forming fastener applications.

The clamp load consistency inhibitor is the focus of this project work. The clamp load consistency concern is founded in the fact that a portion of the input torque used to create clamp load is also used to create threads. The torque used for thread forming may not be consistent due to variations in casting material, hole size and shape due to tooling wear and process variation (thermal and mechanical). There is little data available to understand the magnitude of this concern or to form the basis of potential solutions if the range of clamp load variation is very high $(>+/-30 \%)$.

The following two plots illustrate the consumption of clamp load during the forming of threads. The horizontal scale is rotation measured in degrees. The left vertical scale is clamp load measured in kilonewtons traced as a red line. The right vertical scale is the corresponding input torque measured in newton meters and traced as a turquoise line. The first plot is typical for a machine screw in a drilled and tapped hole. The second plot is typical of a thread forming fastener in a cast hole.

As can be seen in the first plot, the input torque is virtually zero as the machine screw is rotated in the drilled and tapped hole until the head makes contact with the surface. After contact, the input torque rises dramatically as the bolt stretches and the corresponding clamp load increases until failure of the joint. 
In the second plot, the input torque increases with rotation of the thread forming fastener as threads are being formed in the cast hole. When the head of the fastener contacts the surface, input torque and clamp load also increase dramatically. The slope of the line varies as threads are forming is subject to many factors including thread shape, cast material properties, fastener coatings, hole size, draft angle, etc.

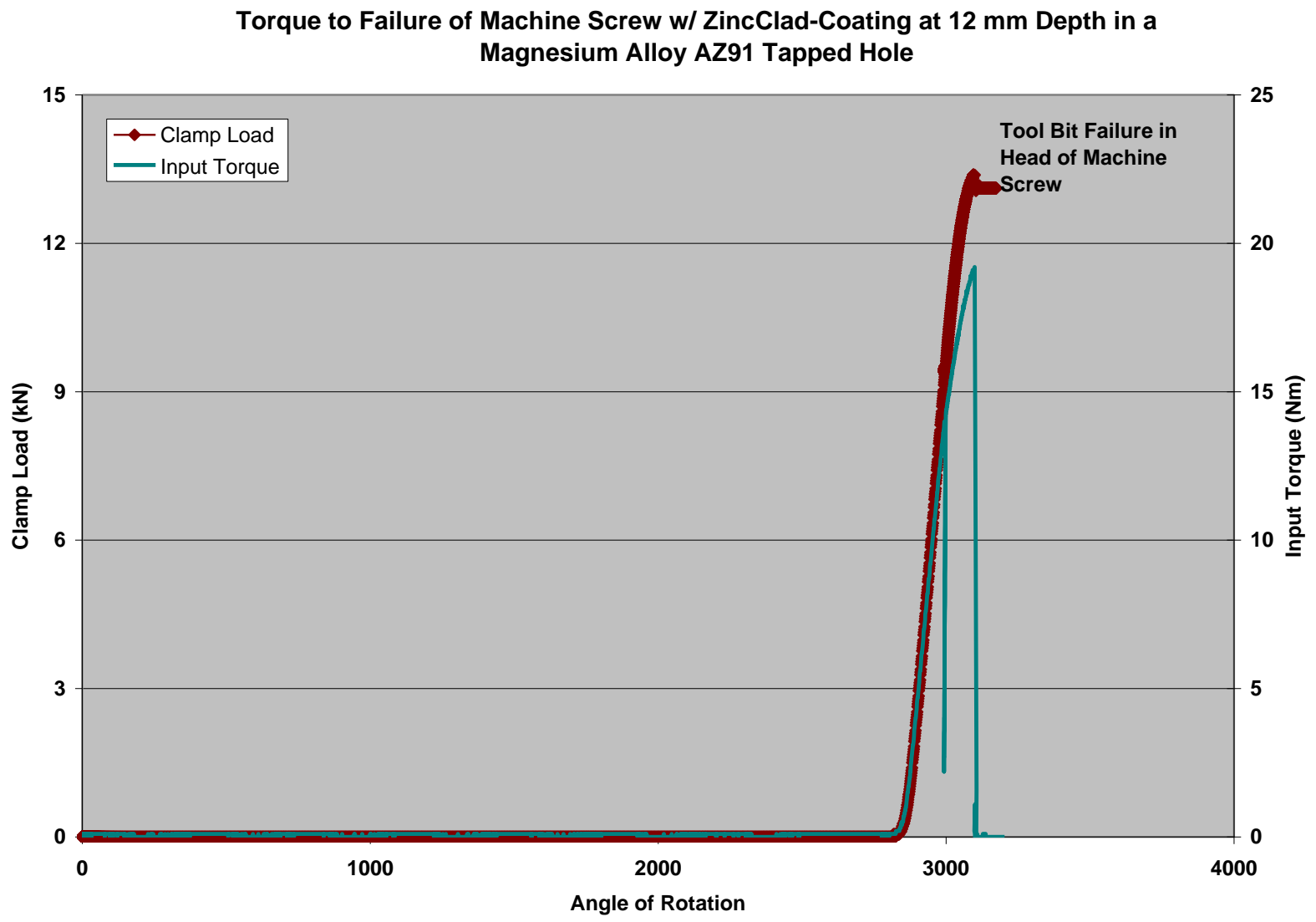

Fig. 7.3 Clamp Load and Input Torque Plot for a Typical Machine Screw 


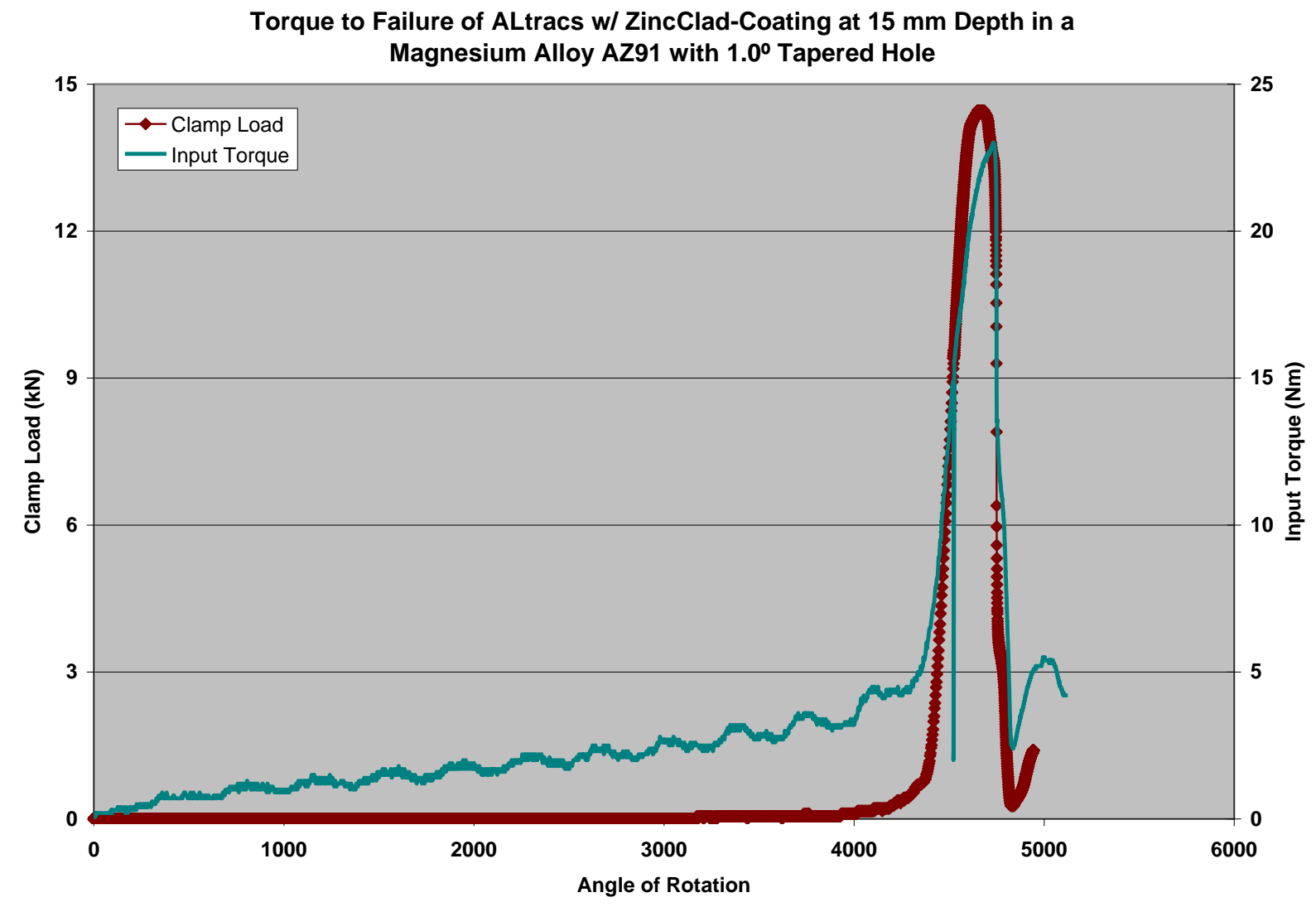

Fig. 7.4 Clamp Load and Input Torque Plot for a Typical Thread Forming Fastener

\subsection{Objective}

The objective of this project was to demonstrate the effectiveness of thread forming fasteners in net shaped as-cast holes in aluminum and magnesium castings. The primary issues to be explored were:

- Consistency of clamp load vs. input torque in either aluminum or magnesium castings.

- Effect on consistency of clamp load as casting dies wear.

The clamp load data gathered in this project when compared to traditional bolts in traditional nuts will determine if any key issues exist inhibiting the widespread adoption of thread forming fasteners in castings. Traditional threaded fasteners in nuts or in drilled and tapped holes achieve clamp loads in a range of $+/-30 \%$ at constant input torque. 


\subsection{Approach}

The range of variation that can be expected in as-cast hole size and shape over the full life cycle of a high pressure die casting die was established in previous work completed by Pacific Northwest National Laboratory, (PNNL). This established range of variation was captured in a set of 12 cast bosses by designing core pins at the size and draft angles identified in the sited previous work. The range is captured in the following chart:

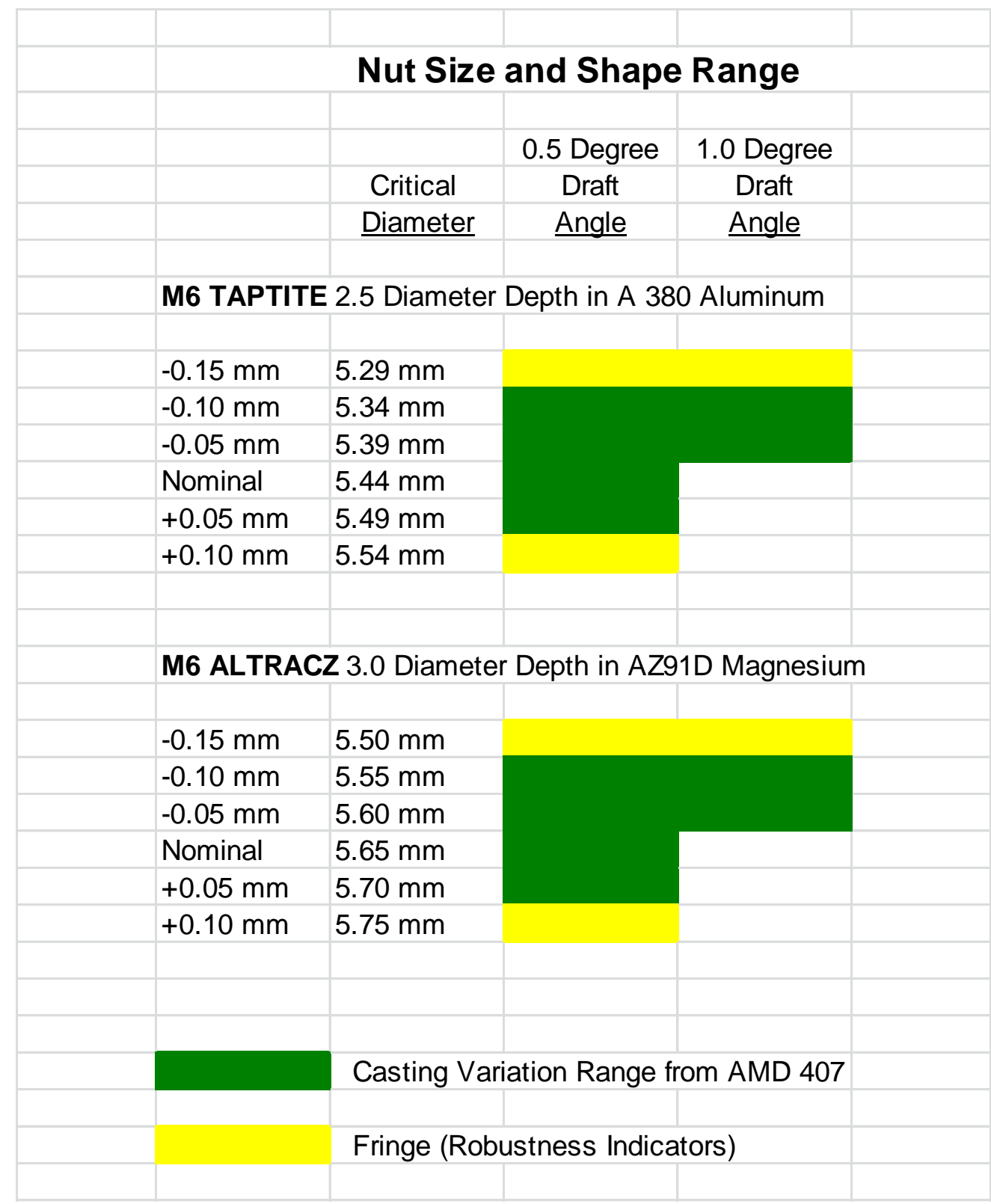

Table 7.1 Cast Hole Size Variation 
An existing die with 12 cast bosses and nuts was used to make the castings.

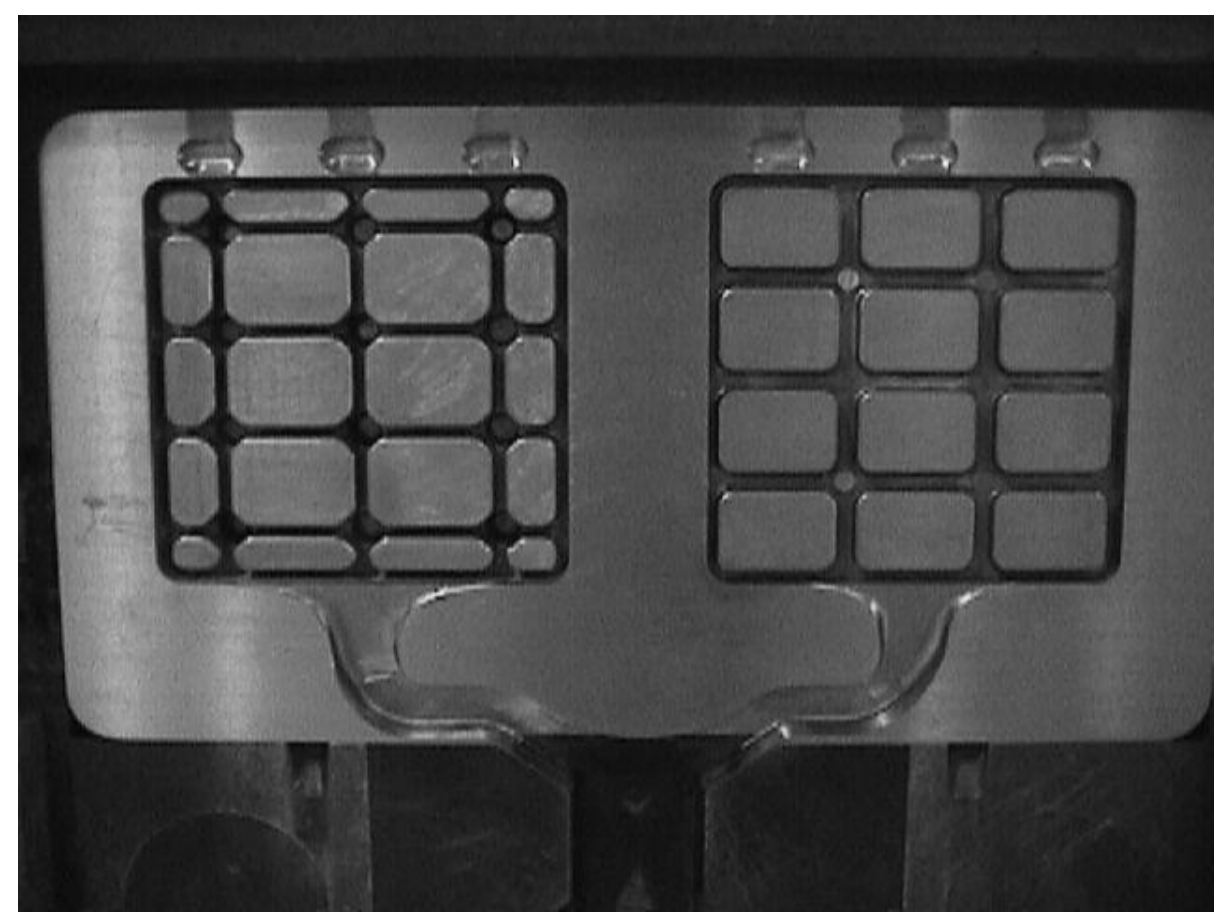

Fig. 7.5 Die with 12 Bosses and 12 Nuts

The cast bosses were cut into "nuts" that could be used in the Ford Fastener Laboratory test-cell to measure clamp load when a thread forming fastener was driven into a cast nut.

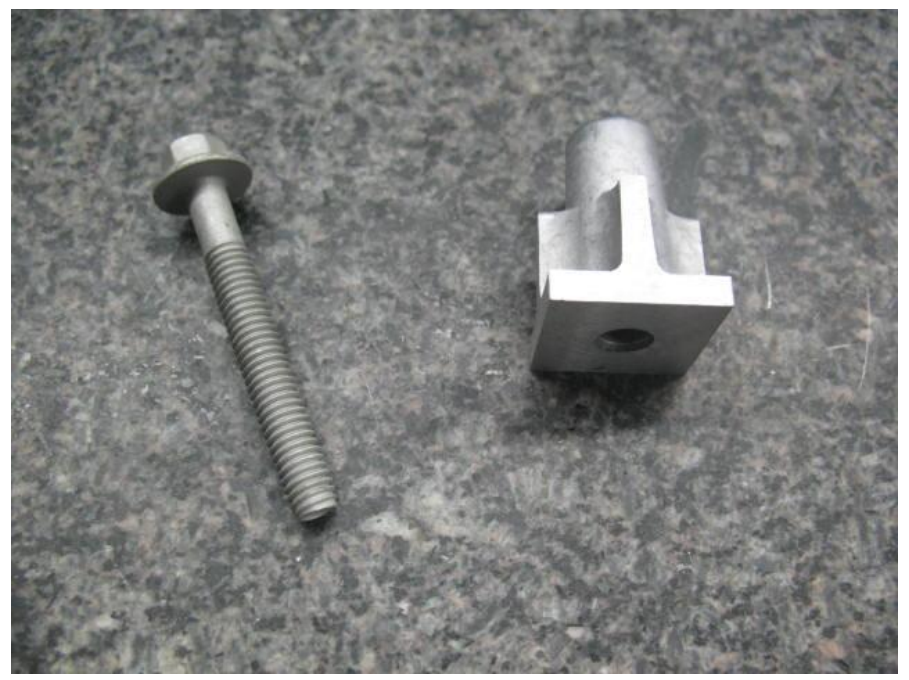

Fig. 7.6 Thread Forming Fastener and Cast Nut 


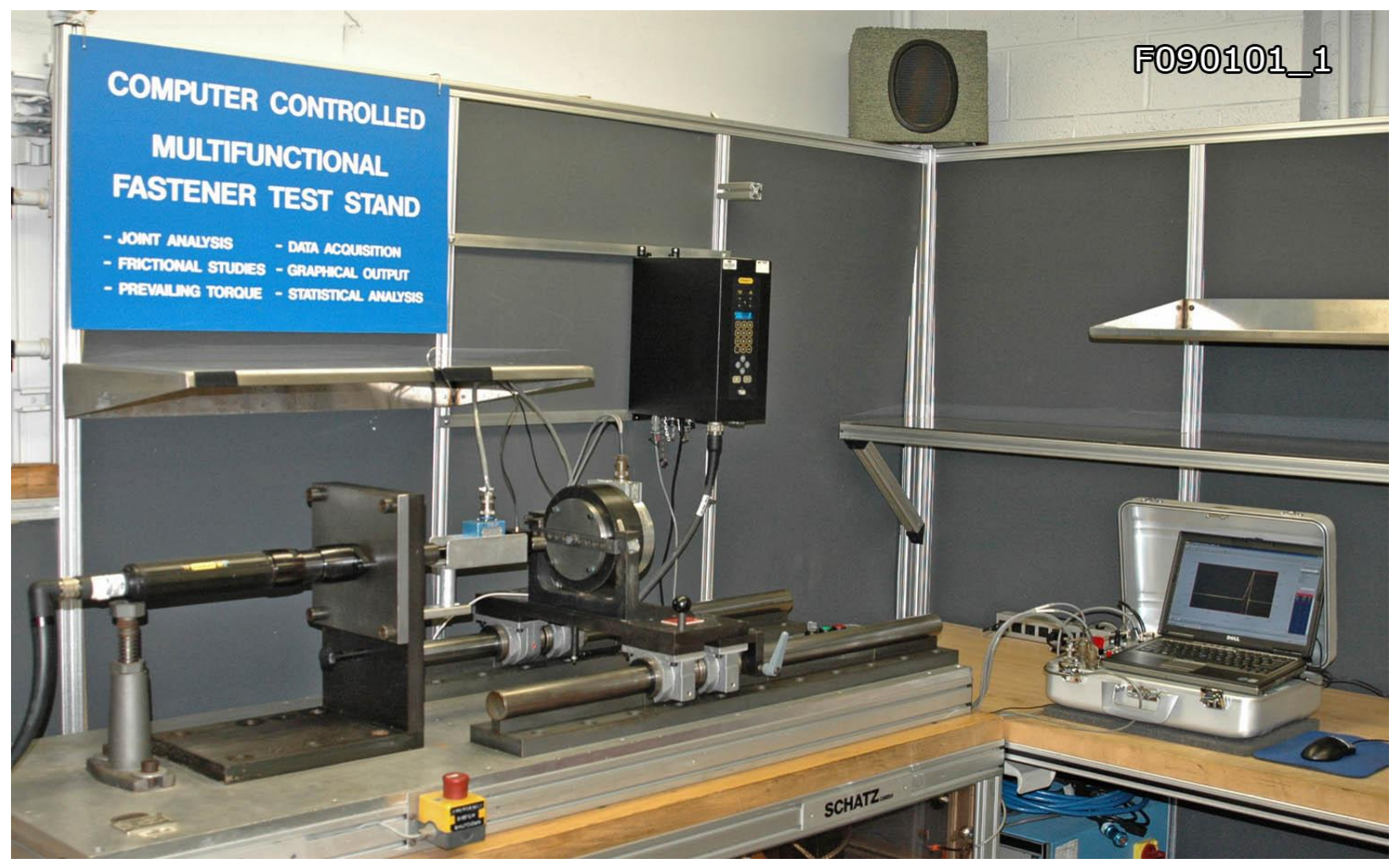

Fig. 7.7 Ford Fastener Laboratory Clamp Load Test Cell

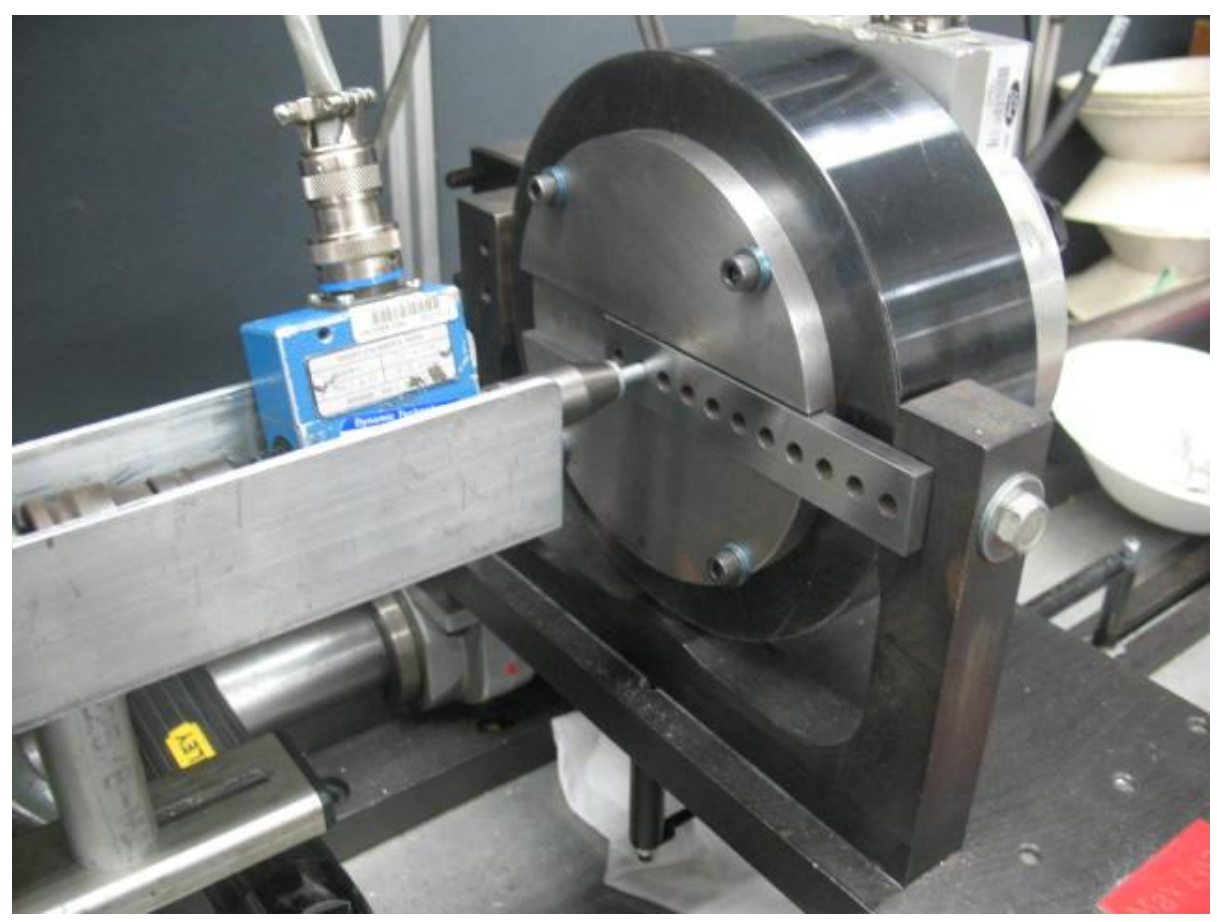

Fig. 7.8 Load Cell with Thread Forming Fastener being Driven into Cast Nut 
There were two sets of experiments run. First, a series of cast aluminum nuts were made reflecting the range of shape and size variations to be expected over the life cycle of a die casting die. Taptite thread forming fasteners, (a widely used thread forming fastener suitable for aluminum applications), were driven into the various cored, as-cast nuts at a constant input torque and resulting clamp loads were recorded continuously. The clamp load data was used to determine the range of clamp loads to be expected. The bolts were driven to failure at constant speed (50 RPM). The clamp load corresponding to the target input of $18.5 \mathrm{Nm}$ was recorded for each fastener.

In a like fashion, a second set of experiments was run with cast magnesium nuts and ALtracs thread forming fasteners, (a widely used thread forming fastener suitable for magnesium applications). Again all clamp loads were recorded and analyzed similarly to the Taptites in aluminum cast nuts.

Four series of test runs were made for each fastener type:

- Out of the box

- Dry bolts with machining oil removed

- Wet bolts with excess machining oil.

These conditions represented the range of oiliness to be expected over time in an automobile manufacturing environment.

In addition a series of test runs was made for robustness $(.05 \mathrm{~mm}$ larger and smaller holes than the expected wear pattern of a die casting die at full life cycle).

After testing was completed, the data was summarized and clamp load ranges were determined.

\subsection{Qualifications and Resources}

The Project Director is William Charron. He has over 34 years of experience at Ford Motor Company, primarily in powertrain operations serving in many engineering functions. He has extensive experience in machining lines and project management for program launch and advanced manufacturing development. He has specific experience in leading fastener development projects at USCAR. He has both technical and management masters degrees.

The Principle Investigator is Todd Cleaver. He retired from Ford Motor Company after 35 years and launched Tech Knowledge, a manufacturing development technical services company. His Ford experiences were in casting and machining with over 20 years in management of advanced engineering projects. He has specific experience in both casting and fastener development projects as well. He has a bachelor's degree in engineering and a master's degree in management.

The test laboratory supervisor is Adrian Cockman. Adrian has 30 years of experience in Ford Motor Company all focused on fastener development and application. He supervised all fastener testing for this project and played a key role in the analysis of the data. He has a degree in engineering. 
The project team consisted of representatives from the US automobile industry, fastener manufacturing industry, the casting supply base, and trade organizations.

The project team has access to a 12 boss die casting die suitable to deliver all cast nuts and washers required for the work described in the work plan. Sufficient production capacity was available in local die casting and machining job shops to assure quick delivery of all cast nuts and washers required.

The Ford Fastener Laboratory performed all fastener testing. It has all the latest stateof-the-art fastener testing hardware and instrumentation including RS technology load cell assessment equipment, Micro Control MC900 data collection systems, a broad spectrum of bolt drivers, transducers, etc. and an experienced staff. 


\subsection{Results and Discussion}

The results are broken into separate sections for aluminum castings and magnesium castings.

\subsection{Aluminum Castings}

This task was designed to determine the full range of clamp load values over the full range of variance in hole shapes and sizes normally experienced by a high pressure die casting die during normal duty cycle. In addition, some hole shapes and sizes, just outside the normal range, were evaluated to acquire a sense for the robustness of the process. Based on previous work done, by others, the range of diameters and draft angles was already established. An available die with 12 bosses was utilized and the core pins were machined with assumed shrinkage values to achieve the established shapes and sizes. The A380 aluminum castings were cut into rectangular nuts for testing. The nominal hole size was determined by the bolt manufacturer providing the fasteners, who also provided technical advice to the team. The thread forming fastener style was a Taptite, (a widely used thread forming fastener suitable for aluminum applications). The nominal fastener size was an M6. A standard automotive fastener coating was applied to all fasteners

All testing occurred at an automotive fastener laboratory equipped with a Load Master test-cell to measure clamp load when the thread forming fastener was driven into each nut. Initially, several thread forming fasteners were driven into nominal diameter, $0.5 \%$ draft angle, nuts at varying input torques to establish the torque setting to be used throughout the remainder of the testing. The input torque selected corresponded to a clamp load of $9.5-10.0 \mathrm{kN}$, the normally expected clamp load for a typical M6 fastener in aluminum. A minimum of 30 fasteners were driven into each size and shape of nuts at the selected constant input torque to establish a data base for evaluation and analysis.

\subsection{A Fasteners Straight Out of the Box}

The initial focus was on the range of variation in cast hole sizes and shapes established by the work done at Pacific Northwest National Laboratory for the typical experience measured for three different production castings. For each cored hole size, 30 fresh bolts, straight out of the box, were driven into 30 fresh cast nuts and the data recorded. The data is summarized in the following chart: 


\section{USCAR FAS1005/ DOE 003482 Project \\ Full Range of Variation \\ M6x1.0 Taptite Fasteners in Aluminum Castings. \\ 2.5 diameter depth $(15 \mathrm{~mm})$.}

\begin{tabular}{|c|c|c|c|c|c|c|}
\hline Pin ID & $\mathbf{A}$ & B & D & $\mathbf{E}$ & I & $\mathbf{J}$ \\
\hline Draft Angle & $0.5 \mathrm{Deg}$. & $0.5 \mathrm{Deg}$. & $0.5 \mathrm{Deg}$. & 0.5 Deg. & $1.0 \mathrm{Deg}$. & 1.0 Deg. \\
\hline Diameter & Nominal & Nom + .05 & Nom - .05 & Nom - .10 & Nom - .05 & Nom - .10 \\
\hline Ultimate Mode & Fractured & Fractured & Fractured & Fractured & Strip/Fracture & Fractured \\
\hline Load at $18.5 \mathrm{Nm}$ & KN & $\mathrm{KN}$ & $\mathrm{KN}$ & KN & KN & $\mathrm{KN}$ \\
\hline MEAN & 9.224 & 9.060 & 8.932 & 8.631 & 9.356 & 9.248 \\
\hline STD DEV & 0.549 & 0.407 & 0.618 & 0.405 & 0.327 & 0.455 \\
\hline X-3STD & 7.577 & 7.837 & 7.077 & 7.415 & 8.374 & 7.883 \\
\hline$X+3 S T D$ & 10.870 & 10.282 & 10.787 & 9.847 & 10.337 & 10.614 \\
\hline MIN & 8.110 & 8.220 & 7.640 & 7.780 & 8.691 & 7.945 \\
\hline \multirow[t]{2}{*}{ MAX } & 10.237 & 9.679 & 10.282 & 9.347 & 10.017 & 10.335 \\
\hline & Peak & Peak & Peak & Peak & Peak & Peak \\
\hline Peak Load & $\mathrm{KN}$ & $\mathrm{KN}$ & $\mathrm{KN}$ & $\mathrm{KN}$ & $\mathrm{KN}$ & $\mathrm{KN}$ \\
\hline MEAN & 12.335 & 11.497 & 12.954 & 13.221 & 11.397 & 11.995 \\
\hline STD DEV & 0.573 & 0.425 & 0.593 & 0.409 & 0.318 & 0.522 \\
\hline$X-3 S T D$ & 10.616 & 10.223 & 11.175 & 11.995 & 10.443 & 10.428 \\
\hline$X+3 S T D$ & 14.054 & 12.770 & 14.733 & 14.448 & 12.351 & 13.562 \\
\hline MIN & 10.574 & 10.508 & 11.535 & 12.231 & 10.939 & 10.475 \\
\hline MAX & 13.159 & 12.198 & 14.088 & 13.922 & 12.032 & 13.027 \\
\hline Torque & Torque & Torque & Torque & Torque & Torque & Torque \\
\hline at Peak Load & $\mathrm{Nm}$ & $\mathrm{Nm}$ & $\mathrm{Nm}$ & $\mathrm{Nm}$ & $\mathrm{Nm}$ & $\mathrm{Nm}$ \\
\hline MEAN & 24.055 & 23.660 & 24.401 & 24.723 & 23.453 & 24.052 \\
\hline STD DEV & 0.540 & 0.589 & 0.453 & 0.442 & 0.473 & 0.418 \\
\hline X-3STD & 22.435 & 21.893 & 23.043 & 23.396 & 22.034 & 22.798 \\
\hline$X+3 S T D$ & 25.676 & 25.428 & 25.760 & 26.049 & 24.872 & 25.307 \\
\hline MIN & 22.615 & 22.728 & 23.622 & 23.735 & 22.488 & 23.319 \\
\hline \multirow[t]{2}{*}{ MAX } & 24.842 & 25.220 & 25.473 & 25.549 & 24.604 & 25.247 \\
\hline & Drive Torque & Drive Torque & Drive Torque & Drive Torque & Drive Torque & Drive Torque \\
\hline Drive Torque & $\mathrm{Nm}$ & $\mathrm{Nm}$ & $\mathrm{Nm}$ & $\mathrm{Nm}$ & $\mathrm{Nm}$ & $\mathrm{Nm}$ \\
\hline MEAN & 6.294 & 5.294 & 7.442 & 8.148 & 5.101 & 6.620 \\
\hline STD DEV & 0.556 & 0.448 & 0.703 & 0.574 & 0.503 & 0.411 \\
\hline X-3STD & 4.626 & 3.951 & 5.331 & 6.425 & 3.592 & 5.389 \\
\hline$X+3$ STD & 7.962 & 6.637 & 9.552 & 9.872 & 6.610 & 7.852 \\
\hline MIN & 4.757 & 4.266 & 6.047 & 6.690 & 3.364 & 5.783 \\
\hline MAX & 7.290 & 6.229 & 9.071 & 9.071 & 6.085 & 7.370 \\
\hline
\end{tabular}

Table 8.1 Data Recorded for Full Range of Cast Hole Size Variation, Straight Out of the Box in Aluminum

The results at $18.5 \mathrm{Nm}$ of input torque showed a minimum clamp load of $7.640 \mathrm{KN}$ and a maximum clamp load of $10.335 \mathrm{KN}$. The range of clamp load variation was 8.9875 $\mathrm{KN}+/-15.0 \%$ over the full range of cast hole sizes. 
The statistical range using $+/-3$ standard deviations showed higher results. The minimum clamp load was $7.077 \mathrm{KN}$ and the maximum was $10.870 \mathrm{KN}$. The statistical range of clamp load variation was $8.9735 \mathrm{KN}+/-21.1 \%$ over the full range of cast hole sizes.

\subsection{B Dry and Lubricated Fasteners}

The next series of tests was on the same range of variation in cast hole sizes and shapes. Only the tightest and loosest holes were tested. The bolts were cleaned with a solvent for the dry bolt tests and the bolts were wiped with a machining fluid for the lubed tests. These conditions represent the extremes of oiliness that could be encountered in the manufacturing environment. For each cored hole size, 10 fresh bolts were driven into 10 fresh cast nuts and the data recorded. The data is summarized in the following chart:

\begin{tabular}{|c|c|c|c|c|}
\hline \multicolumn{5}{|c|}{ USCAR FAS1005/DOE 003482 Project } \\
\hline \multicolumn{5}{|c|}{ Dry and Lubed Conditions Range of Variation } \\
\hline \multirow{2}{*}{\multicolumn{5}{|c|}{$\begin{array}{l}\text { M6x1.0 Taptite Fasteners in Aluminum Castings. } \\
2.5 \text { diameter depth }(15 \mathrm{~mm}) .\end{array}$}} \\
\hline & & & & \\
\hline Pin ID & B & E & I & $\mathbf{J}$ \\
\hline Draft Angle & 0.5 Deg. & $0.5 \mathrm{Deg}$. & 1.0 Deg. & 1.0 Deg. \\
\hline \multirow[t]{2}{*}{ Diameter } & Nom +.05 & Nom -.10 & Nom - .05 & Nom -.10 \\
\hline & DRY & DRY & DRY & DRY \\
\hline Load at $18.5 \mathrm{Nm}$ & KN & $\mathrm{KN}$ & KN & KN \\
\hline MEAN & 9.229 & 9.060 & 9.156 & 8.993 \\
\hline STD DEV & 0.353 & 0.691 & 0.305 & 0.236 \\
\hline$X-3 S T D$ & 8.170 & 6.988 & 8.240 & 8.285 \\
\hline$X+3 S T D$ & 10.288 & 11.132 & 10.072 & 9.700 \\
\hline MIN & 8.869 & 8.312 & 8.968 & 8.803 \\
\hline \multirow[t]{2}{*}{ MAX } & 9.575 & 9.674 & 9.508 & 9.257 \\
\hline & LUBED & LUBED & LUBED & LUBED \\
\hline Load at $18.5 \mathrm{Nm}$ & KN & KN & KN & KN \\
\hline MEAN & 11.178 & 11.925 & 11.163 & 11.771 \\
\hline STD DEV & 0.084 & 0.931 & 0.555 & 0.270 \\
\hline$X-3 S T D$ & 10.927 & 9.130 & 9.498 & 10.960 \\
\hline$X+3 S T D$ & 11.429 & 14.719 & 12.827 & 12.582 \\
\hline MIN & 11.122 & 10.860 & 10.535 & 11.542 \\
\hline MAX & 11.274 & 12.589 & 11.589 & 12.069 \\
\hline
\end{tabular}

Table 8.2 Data Recorded for Full Range of Cast Hole Size Variation, Dry and Lubed in Aluminum 
The results at $18.5 \mathrm{Nm}$ of input torque showed a minimum clamp load of $8.313 \mathrm{KN}$ and a maximum clamp load of $12.589 \mathrm{KN}$. The range of clamp load variation was 10.451 $\mathrm{KN}+/-20.5 \%$ over the selected range of cast hole sizes.

The statistical range using $+/-3$ standard deviations showed higher results. The minimum clamp load was $6.988 \mathrm{KN}$ and the maximum was $14.719 \mathrm{KN}$. The statistical range of clamp load variation was $10.8535 \mathrm{KN}+/-35.6 \%$ over the selected range of cast hole sizes.

\subsection{Robustness Testing}

The next series of tests was on a wider range of variation in cast hole sizes and shapes. The object was to see what happened to clamp load variation if the hole sizes were .05 $\mathrm{mm}$ larger or smaller than the range established by the Pacific Northwest National Laboratory. Only the tightest and loosest holes were tested. Bolts for these tests were taken straight from the box. No lubed or dry bolts were considered. For each cored hole size, 10 fresh bolts were driven into 10 fresh cast nuts and the data recorded. The data is summarized in the following chart: 


\begin{tabular}{|c|c|c|c|c|}
\hline \multicolumn{5}{|c|}{ USCAR FAS1005/DOE 003482 Project } \\
\hline \multicolumn{5}{|c|}{ Robustness Range of Variation } \\
\hline \multicolumn{5}{|c|}{ M6x1.0 Taptite Fasteners in Aluminum Castings. } \\
\hline \multicolumn{5}{|c|}{2.5 diameter depth $(15 \mathrm{~mm})$. } \\
\hline Pin ID & C & $\mathbf{F}$ & $\mathbf{G}$ & $\mathbf{K}$ \\
\hline Draft Angle & $0.5 \mathrm{Deg}$. & $0.5 \mathrm{Deg}$. & $1.0 \mathrm{Deg}$. & $1.0 \mathrm{Deg}$. \\
\hline Diameter & Nom +.10 & Nom - .15 & Nominal & Nom - .15 \\
\hline Ultimate Mode & Fractured & Fractured & Stripped & Fractured \\
\hline Load at $18.5 \mathrm{Nm}$ & $\mathrm{KN}$ & KN & KN & KN \\
\hline MEAN & 8.237 & 7.704 & 8.763 & 9.141 \\
\hline STD DEV & 0.498 & 0.453 & 0.379 & 0.401 \\
\hline X-3STD & 6.744 & 6.346 & 7.625 & 7.940 \\
\hline$X+3 S T D$ & 9.730 & 9.061 & 9.901 & 10.343 \\
\hline MIN & 7.160 & 6.610 & 7.345 & 8.237 \\
\hline MAX & 9.109 & 8.539 & 9.347 & 9.977 \\
\hline & Peak & Peak & Peak & Peak \\
\hline Peak Load & $\mathrm{KN}$ & $\mathrm{KN}$ & $\mathrm{KN}$ & $\mathrm{KN}$ \\
\hline MEAN & 9.902 & 13.162 & 10.407 & 12.262 \\
\hline STD DEV & 0.594 & 0.514 & 0.467 & 0.479 \\
\hline X-3STD & 8.120 & 11.620 & 9.005 & 10.826 \\
\hline $\mathrm{X}+3$ STD & 11.685 & 14.703 & 11.809 & 13.698 \\
\hline MIN & 8.419 & 12.231 & 8.651 & 11.171 \\
\hline MAX & 11.071 & 13.988 & 11.137 & 13.093 \\
\hline Torque & Torque & Torque & Torque & Torque \\
\hline at Peak Load & $\mathrm{Nm}$ & $\mathrm{Nm}$ & $\mathrm{Nm}$ & $\mathrm{Nm}$ \\
\hline MEAN & 23.093 & 24.785 & 23.122 & 24.162 \\
\hline STD DEV & 0.515 & 0.316 & 0.413 & 0.509 \\
\hline X-3STD & 21.547 & 23.838 & 21.883 & 22.634 \\
\hline$X+3$ STD & 24.639 & 25.732 & 24.362 & 25.690 \\
\hline MIN & 22.350 & 24.175 & 22.148 & 23.168 \\
\hline MAX & 24.729 & 25.686 & 24.062 & 25.020 \\
\hline & Drive Torque & Drive Torque & Drive Torque & Drive Torque \\
\hline Drive Torque & $\mathrm{Nm}$ & $\mathrm{Nm}$ & $\mathrm{Nm}$ & $\mathrm{Nm}$ \\
\hline MEAN & 4.271 & 10.244 & 4.554 & 7.241 \\
\hline STD DEV & 0.514 & 0.696 & 0.457 & 0.585 \\
\hline X-3STD & 2.729 & 8.157 & 3.182 & 5.487 \\
\hline$X+3 S T D$ & 5.813 & 12.332 & 5.925 & 8.996 \\
\hline MIN & 3.436 & 9.292 & 3.439 & 5.858 \\
\hline MAX & 5.927 & 12.541 & 5.253 & 8.315 \\
\hline
\end{tabular}

Table 8.3 Data Recorded for Robustness Range of Cast Hole Size Variation in Aluminum 
The results at $18.5 \mathrm{Nm}$ of input torque showed a minimum clamp load of $6.610 \mathrm{KN}$ and a maximum clamp load of $9.977 \mathrm{KN}$. The range of clamp load variation was $8.2935 \mathrm{KN}$ $+/-20.3 \%$ over the selected range of cast hole sizes.

The statistical range using $+/-3$ standard deviations showed higher results. The minimum clamp load was $6.346 \mathrm{KN}$ and the maximum was $10.343 \mathrm{KN}$. The statistical range of clamp load variation was $8.3445 \mathrm{KN}+/-23.9 \%$ over the selected range of cast hole sizes.

\subsection{Magnesium Castings}

The magnesium casting work was a duplication of the aluminum casting work with a substitution of the fastener style and the casting material. This work evaluated ALtracs thread forming fasteners (a widely used thread forming fastener suitable for magnesium applications), in AZ91D magnesium cast nuts.

\subsection{A Fasteners Straight Out of the Box}

The initial focus was on the range of variation in cast hole sizes and shapes established by the work done at Pacific Northwest National Laboratory for the typical experience measured for three different production castings. For each cored hole size, 30 fresh bolts, straight out of the box, were driven into 30 fresh cast nuts and the data recorded. The data is summarized in the following chart: 


\section{USCAR FAS1005/ DOE 003482 Project}

\section{Full Range of Variation}

\section{M6x1.0 ALtracs Fasteners in Magnesium Castings.}

3.0 diameter depth $(18 \mathrm{~mm})$.

\begin{tabular}{|c|c|c|c|c|c|c|}
\hline Pin ID & A & B & D & E & I & J \\
\hline Draft Angle & 0.5 Deg. & 0.5 Deg. & 0.5 Deg. & 0.5 Deg. & 1.0 Deg. & 1.0 Deg. \\
\hline Diameter & Nominal & Nom + .05 & Nom - .05 & Nom - .10 & Nom - .05 & Nom - .10 \\
\hline Ultimate Mode & Stripped & Stripped & Stripped & Stripped & Stripped & Stripped \\
\hline Load at $10.6 \mathrm{Nm}$ & KN & KN & KN & KN & KN & KN \\
\hline MEAN & 9.225 & 8.781 & 9.387 & 9.228 & 9.172 & 9.058 \\
\hline STD DEV & 0.378 & 0.542 & 0.569 & 0.479 & 0.508 & 0.496 \\
\hline X-3STD & 8.09 & 7.156 & 7.68 & 7.791 & 7.648 & 7.571 \\
\hline$X+3 S T D$ & 10.36 & 10.406 & 11.094 & 10.665 & 10.696 & 10.546 \\
\hline MIN & 8.575 & 7.962 & 8.472 & 8.313 & 8.167 & 7.876 \\
\hline \multirow[t]{2}{*}{ MAX } & 10.087 & 9.765 & 11.051 & 10.143 & 10.508 & 10.209 \\
\hline & Peak & Peak & Peak & Peak & Peak & Peak \\
\hline Peak Load & $\mathrm{KN}$ & $\mathrm{KN}$ & KN & $\mathrm{KN}$ & KN & KN \\
\hline MEAN & 14.553 & 12.154 & 15.923 & 16.626 & 15.578 & 16.592 \\
\hline STD DEV & 0.395 & 0.433 & 0.386 & 0.249 & 0.319 & 0.228 \\
\hline X-3STD & 13.368 & 10.854 & 14.766 & 15.879 & 14.621 & 15.91 \\
\hline$X+3 S T D$ & 15.737 & 13.454 & 17.08 & 17.372 & 16.535 & 17.275 \\
\hline MIN & 13.889 & 11.237 & 14.618 & 16.242 & 14.883 & 16.076 \\
\hline MAX & 15.48 & 13.126 & 16.507 & 17.071 & 16.275 & 17.071 \\
\hline Torque & Torque & Torque & Torque & Torque & Torque & Torque \\
\hline at Peak Load & $\mathrm{Nm}$ & $\mathrm{Nm}$ & $\mathrm{Nm}$ & $\mathrm{Nm}$ & $\mathrm{Nm}$ & $\mathrm{Nm}$ \\
\hline MEAN & 18.53 & 17.289 & 18.594 & 18.411 & 18.313 & 18.192 \\
\hline STD DEV & 0.669 & 1.132 & 0.685 & 0.527 & 0.412 & 0.489 \\
\hline X-3STD & 16.523 & 13.892 & 16.538 & 16.831 & 17.076 & 16.724 \\
\hline$X+3 S T D$ & 20.538 & 20.686 & 20.649 & 19.991 & 19.55 & 19.66 \\
\hline MIN & 16.714 & 14.483 & 16.403 & 16.923 & 17.461 & 17.301 \\
\hline \multirow[t]{2}{*}{ MAX } & 19.664 & 18.756 & 19.945 & 19.378 & 19.048 & 19.152 \\
\hline & Drive Torque & Drive Torque & Drive Torque & Drive Torque & Drive Torque & Drive Torque \\
\hline Drive Torque & $\mathrm{Nm}$ & $\mathrm{Nm}$ & $\mathrm{Nm}$ & $\mathrm{Nm}$ & $\mathrm{Nm}$ & $\mathrm{Nm}$ \\
\hline MEAN & 2.421 & 2.061 & 2.835 & 3.225 & 3.117 & 3.527 \\
\hline STD DEV & 0.291 & 0.273 & 0.357 & 0.497 & 0.277 & 0.389 \\
\hline X-3STD & 1.55 & 1.241 & 1.763 & 1.735 & 2.286 & 2.36 \\
\hline$X+3 S T D$ & 3.293 & 2.881 & 3.906 & 4.714 & 3.947 & 4.693 \\
\hline MIN & 1.929 & 1.55 & 2.229 & 2.115 & 2.494 & 2.946 \\
\hline MAX & 3.025 & 2.836 & 3.664 & 4.231 & 3.628 & 4.382 \\
\hline
\end{tabular}

Table 8.4 Data Recorded for Full Range of Cast Hole Size Variation, Straight out of the Box in Magnesium

The results at $18.5 \mathrm{Nm}$ of input torque showed a minimum clamp load of $7.876 \mathrm{KN}$ and a maximum clamp load of $11.051 \mathrm{KN}$. The range of clamp load variation was 9.4635 $\mathrm{KN}+/-16.8 \%$ over the full range of cast hole sizes. 
The statistical range using $+/-3$ standard deviations showed higher results. The minimum clamp load was $7.156 \mathrm{KN}$ and the maximum was $11.094 \mathrm{KN}$. The statistical range of clamp load variation was $9.125 \mathrm{KN}+/-21.6 \%$ over the full range of cast hole sizes.

\subsection{B Dry and Lubricated Fasteners}

The next series of tests was on the same range of variation in cast hole sizes and shapes. Only the tightest and loosest holes were tested. The bolts were cleaned with a solvent for the dry bolt tests and the bolts were wiped with a machining fluid for the lubed tests. These conditions represent the extremes of oiliness that could be encountered in the manufacturing environment. For each cored hole size, 10 fresh bolts were driven into 10 fresh cast nuts and the data recorded. The data is summarized in the following chart:

\begin{tabular}{|c|c|c|c|c|}
\hline \multicolumn{5}{|c|}{ USCAR FAS1005/DOE 003482 Project } \\
\hline \multicolumn{5}{|c|}{ Dry and Lubed Conditions Range of Variation } \\
\hline \multicolumn{5}{|c|}{$\begin{array}{l}\text { M6x1.0 ALtracs Fasteners in Magnesium Castings. } \\
\text { 3.0 diameter depth }(18 \mathrm{~mm})\end{array}$} \\
\hline Pin ID & B & E & I & $\mathbf{J}$ \\
\hline Draft Angle & $0.5 \mathrm{Deg}$. & $0.5 \mathrm{Deg}$. & 1.0 Deg. & 1.0 Deg. \\
\hline \multirow[t]{2}{*}{ Diameter } & $\mathrm{Nom}+.05$ & Nom -.10 & Nom -.05 & Nom -.10 \\
\hline & DRY & DRY & DRY & DRY \\
\hline Load at $18.5 \mathrm{Nm}$ & KN & KN & KN & KN \\
\hline MEAN & 8.711 & 9.353 & 9.362 & 8.812 \\
\hline STD DEV & 0.490 & 0.520 & 0.399 & 0.351 \\
\hline $\mathrm{X}-3 \mathrm{STD}$ & 7.240 & 7.794 & 8.165 & 7.758 \\
\hline$X+3 S T D$ & 10.182 & 10.912 & 10.558 & 9.866 \\
\hline MIN & 8.213 & 8.680 & 8.614 & 8.279 \\
\hline \multirow[t]{2}{*}{ MAX } & 9.803 & 10.499 & 9.806 & 9.276 \\
\hline & LUBED & LUBED & LUBED & LUBED \\
\hline Load at $18.5 \mathrm{Nm}$ & KN & KN & KN & KN \\
\hline MEAN & 9.342 & 10.334 & 10.411 & 10.513 \\
\hline STD DEV & 0.252 & 0.372 & 0.096 & 0.069 \\
\hline X-3STD & 8.586 & 9.217 & 10.124 & 10.306 \\
\hline$X+3 S T D$ & 10.097 & 11.452 & 10.697 & 10.720 \\
\hline MIN & 9.074 & 10.101 & 10.300 & 10.436 \\
\hline MAX & 9.575 & 10.764 & 10.466 & 10.568 \\
\hline
\end{tabular}

Table 8.5 Data Recorded for Full Range of Cast Hole Size Variation, Dry and Lubed in Magnesium 
The results at $18.5 \mathrm{Nm}$ of input torque showed a minimum clamp load of $8.213 \mathrm{KN}$ and a maximum clamp load of $10.764 \mathrm{KN}$. The range of clamp load variation was 9.4885 $\mathrm{KN}+/-13.4 \%$ over the selected range of cast hole sizes.

The statistical range using $+/-3$ standard deviations showed higher results. The minimum clamp load was $7.240 \mathrm{KN}$ and the maximum was $11.452 \mathrm{KN}$. The statistical range of clamp load variation was $9.346 \mathrm{KN}+/-22.5 \%$ over the selected range of cast hole sizes.

\subsection{Robustness Testing}

The next series of tests was on a wider range of variation in cast hole sizes and shapes. The object was to see what happened to clamp load variation if the hole sizes were .05 $\mathrm{mm}$ larger or smaller than the range established by the Pacific Northwest National Laboratory. Only the tightest and loosest holes were tested. Bolts for these tests were taken straight from the box. No lubed or dry bolts were considered. For each cored hole size, 10 fresh bolts were driven into 10 fresh cast nuts and the data recorded. The data is summarized in the following chart: 


\begin{tabular}{|c|c|c|c|c|}
\hline \multicolumn{5}{|c|}{ USCAR FAS1005/DOE 003482 Project } \\
\hline \multicolumn{5}{|c|}{ Robustness Range of Variation } \\
\hline \multicolumn{5}{|c|}{ M6x1.0 ALtracs Fasteners in Magnesium Castings. } \\
\hline \multicolumn{5}{|c|}{3.0 diameter depth $(18 \mathrm{~mm})$. } \\
\hline Pin ID & C & $\mathbf{F}$ & $\mathbf{G}$ & $\mathbf{K}$ \\
\hline Draft Angle & $0.5 \mathrm{Deg}$. & $0.5 \mathrm{Deg}$. & $1.0 \mathrm{Deg}$. & 1.0 Deg. \\
\hline Diameter & Nom + .10 & Nom - .15 & Nominal & Nom - .15 \\
\hline Ultimate Mode & Stripped & Stripped & Stripped & Stripped \\
\hline Load at $10.6 \mathrm{Nm}$ & KN & KN & KN & KN \\
\hline MEAN & 8.23 & 9.178 & 9.139 & 8.879 \\
\hline STD DEV & 0.459 & 0.487 & 0.374 & 0.544 \\
\hline$X-3 S T D$ & 6.853 & 7.718 & 8.016 & 7.248 \\
\hline$X+3 S T D$ & 9.607 & 10.638 & 10.262 & 10.51 \\
\hline MIN & 7.316 & 8.416 & 8.466 & 7.823 \\
\hline \multirow[t]{2}{*}{ MAX } & 9.086 & 10.216 & 9.944 & 10.037 \\
\hline & Peak & Peak & Peak & Peak \\
\hline Peak Load & KN & KN & KN & KN \\
\hline MEAN & 10.069 & 16.798 & 13.99 & 16.791 \\
\hline STD DEV & 0.344 & 0.217 & 0.459 & 0.194 \\
\hline X-3STD & 9.036 & 16.146 & 12.614 & 16.208 \\
\hline$X+3$ STD & 11.103 & 17.449 & 15.367 & 17.374 \\
\hline MIN & 9.016 & 16.342 & 13.126 & 16.308 \\
\hline MAX & 10.475 & 17.071 & 14.784 & 17.369 \\
\hline Torque & Torque & Torque & Torque & Torque \\
\hline at Peak Load & $\mathrm{Nm}$ & $\mathrm{Nm}$ & $\mathrm{Nm}$ & $\mathrm{Nm}$ \\
\hline MEAN & 15.233 & 18.04 & 17.469 & 17.725 \\
\hline STD DEV & 1.128 & 0.36 & 0.728 & 0.433 \\
\hline X-3STD & 11.848 & 16.96 & 15.287 & 16.427 \\
\hline$X+3$ STD & 18.618 & 19.12 & 19.652 & 19.023 \\
\hline MIN & 12.744 & 17.414 & 15.752 & 16.772 \\
\hline \multirow[t]{2}{*}{ MAX } & 16.752 & 18.66 & 18.698 & 18.509 \\
\hline & Drive Torque & Drive Torque & Drive Torque & Drive Torque \\
\hline Drive Torque & $\mathrm{Nm}$ & $\mathrm{Nm}$ & $\mathrm{Nm}$ & $\mathrm{Nm}$ \\
\hline MEAN & 1.703 & 3.668 & 2.62 & 3.966 \\
\hline STD DEV & 0.149 & 0.445 & 0.217 & 0.355 \\
\hline X-3STD & 1.256 & 2.332 & 1.97 & 2.901 \\
\hline$X+3 S T D$ & 2.15 & 5.004 & 3.271 & 5.031 \\
\hline MIN & 1.361 & 2.909 & 2.191 & 3.173 \\
\hline MAX & 1.966 & 4.495 & 3.06 & 4.911 \\
\hline
\end{tabular}

Table 8.6 Data Recorded for Robustness Range of Cast Hole Size Variation in Magnesium 
The results at $18.5 \mathrm{Nm}$ of input torque showed a minimum clamp load of $7.316 \mathrm{KN}$ and a maximum clamp load of $10.216 \mathrm{KN}$. The range of clamp load variation was $8.766 \mathrm{KN}$ $+/-16.5 \%$ over the selected range of cast hole sizes.

The statistical range using $+/-3$ standard deviations showed higher results. The minimum clamp load was $6.853 \mathrm{KN}$ and the maximum was $10.343 \mathrm{KN}$. The statistical range of clamp load variation was $8.598 \mathrm{KN}+/-20.3 \%$ over the selected range of cast hole sizes.

\subsection{Discussion}

Maintaining variation at the lowest possible level is a common objective throughout all manufacturing operations. Variation is often at the root of quality and customer satisfaction issues. One of the common tools used for measuring variation in process analyses is the standard deviation. The plus or minus 3 standard deviations to the average is the measurement of choice for our project team. Therefore that is the data to be used to summarize the results. The simple calculation is as follows:

$$
\begin{aligned}
& + \text { Range }=(((x+3 s t d))-((x+3 s t d)+(x-3 s t d)) / 2) /(((x+3 s t d)+(x-3 s t d)) / 2) \\
& - \text { Range }=(((x-3 s t d))-((x+3 s t d)+(x-3 s t d)) / 2) /(((x+3 s t d)+(x-3 s t d)) / 2)
\end{aligned}
$$

Where:

$x+3 s t d=$ the mean plus 3 standard deviations of the respective fastener set, $x-3 s t d=$ the mean minus 3 standard deviations of the respective fastener set, The results of the various test runs are summarized in the following table: 


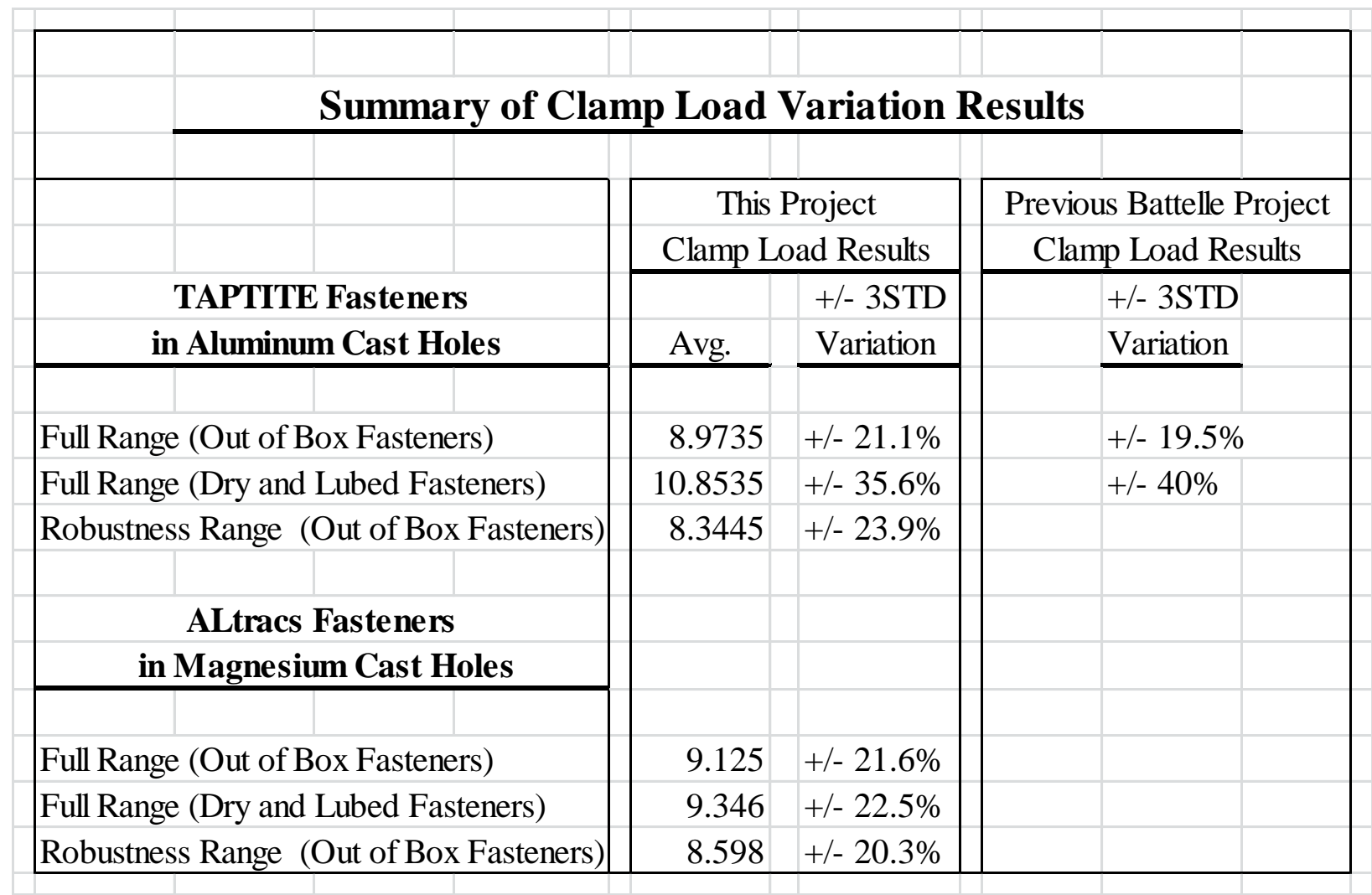

Table 8.7 Summary of Clamp Load Variation Results

The table above summarizes the results of the 6 sets of experiments conducted in this project. Also shown in this table are results from previous work (see References: USCAR Project JNG 601), performed on the same test cell for a Battelle project using standard M8 bolts into standard M8 nuts. The Battelle work results are included as a comparator for a standard bolt and nut application.

The results for the thread forming fasteners in aluminum cast holes are well within industry expectations of $+/-30 \%$ for out of the box and robustness range testing. The results for the dry and lubed extreme conditions are only slightly higher than industry expectations at $+/-35.6 \%$. However, when compared to the actual Battelle results (+/$40 \%)$ for a standard bolt and nut the thread forming fasteners performed slightly better.

The results for the thread forming fasteners in magnesium cast holes are well within industry expectations of $+/-30 \%$ for all three conditions.

The robustness range $(.05 \mathrm{~mm}$ larger and smaller holes than the expected wear pattern of a die casting die at full life cycle) results also fell within the industry expectations for standard threaded fasteners. These results were very encouraging. 


\subsection{Benefits Assessment}

\subsection{Advantages over Traditional Threaded Fasteners}

There are several advantages to the manufacturer in application of thread forming fasteners, especially if the fasteners can be applied directly to as-cast holes. The most significant is the elimination of several expensive, capital intensive machining operations. The current methods require a drilling operation followed by a probing station to assure a complete, unobstructed hole has been accomplished. This is followed by a tapping operation and cleaning process to assure all debris resulting from the previous cutting steps has been removed from the hole. Gaging is required throughout. In addition, a very significant coolant and chip removal system is required. All of these steps are not required if this new technology is fully developed and the equivalent clamp load can be achieved.

Proprietary studies performed within the North American automotive industry indicate that at least $30 \%$ of all machining energy in a typical powertrain (engine or transmission) plant is consumed in the drilling and tapping of holes for fasteners. Other recent proprietary studies in the domestic automotive industry indicate operating cost savings of $\$ .07$ to $\$ .09$ per fastener.

There are several additional advantages to be considered:

- Cross threading is not possible resulting in higher productivity, improved quality, less warranty concerns

- Stronger internal threads due to the cold flow work hardening during thread formation

- Elimination of chip handling and reprocessing

- Elimination of fastener locking features like lock washers due to the superior vibration resistance of the lobular design, also resulting in less warranty calls for squeaks and rattles

- Environmental improvement due to elimination of machining coolant

- Enabler to lightweight material substitution (CAFÉ improvement) through reduction in cost differential between lightweight materials (Al. and Mg.) and ferrous materials.

In summary, when fully implemented, the application of thread forming fasteners would result in the elimination of machining centers for drilling and tapping, gaging stations, automated stations for probing and cleaning, material handling between stations, coolant systems for machining centers, chip handling and recovery systems, significant manufacturing floor space, and associated building facilities like HVAC, lighting, and human necessities and conveniences. 


\subsection{Automotive Applications}

\subsection{A Potential Energy Benefits}

An average automotive powertrain (engine, transmission through rear axles) has more than 500 threaded fasteners. At least $60 \%$ of these fasteners are realistic candidates for replacement by thread forming fasteners. Proprietary Corporate Plant Engineering studies at one of the US automobile manufacturers have estimated that machining in automotive powertrain plants accounts for $0.90 \mathrm{mmbtu}$ per unit (vehicle). It was also estimated that $30 \%$ of that energy was identified with creating drilled and tapped holes. Assuming $60 \%$ of the drilled and tapped holes could be eliminated then the calculation for energy savings to a typical automotive powertrain would be:

$60 \%$ of $30 \%$ of $0.90 \mathrm{mmbtu} / \mathrm{unit}$ or $0.162 \mathrm{mmbtu} / \mathrm{unit}$.

If 16 million powertrains are produced per year in North America, the resulting energy save could be:

$0.162 \mathrm{mmbtu} / \mathrm{unit} \times 16$ million units/year or 2.59 trillion btu/year.

There are an estimated 200 additional candidate fasteners for replacement with thread forming fasteners in chassis, (control arms, suspensions), body structures that utilize large castings (inner doors, lift gates, under-hood attachments and supports), and interior assemblies (instrument panels, steering columns, seat structures and accessories). If energy savings proportional to the potential powertrain savings can be achieved an additional 1.73 trillion btu/year can be realized.

The total direct energy savings identified is therefore, 4.32 trillion btu/year. Further energy savings can result from the elimination of parts resulting from use of thread forming fasteners:

- Elimination of manufacturing energy for locking materials such as lock washers or cementing fluids like Locktite.

- Elimination of tool manufacturing energy consumption through elimination of drills, taps, probes and gages.

- If aluminum thread forming fasteners can be made to work in magnesium castings, corrosion preventing isolating washers, sleeves and separation plates could be eliminated further reducing parts and their corresponding manufacturing energy consumption.

- Fewer parts to handle would result in reduced assembly operations energy consumption as well

Further energy savings would result from the elimination of chip reprocessing and coolant reprocessing and disposal. Finally, the energy savings resulting from never having to build machining centers, automation, chip handling, coolant handling and building space for new model lines and Greenfield sites would add significant one time energy savings as well.

Ultimately, in excess of 5 trillion btu/year appears feasible as a result of full implementation of this technology in the North American automotive industry. 


\subsection{B Potential Economic Benefits}

Recent proprietary automotive studies indicate fully accounted operating cost savings of $\$ .07$ to $\$ .09$ per fastener are achievable when thread forming fasteners are substituted for traditional threaded fasteners in drilled and tapped holes in cast light metal components. Taken into account in these studies are direct and indirect labor, energy, maintenance, tooling, amortization of assets, chip and cooling handling costs, quality improvement, etc. Warranty cost reductions due to improved clamp load retention characteristics and elimination of cost threading are above and beyond the studied cost savings.

\subsection{Potential Environmental Benefits}

Using the same assumptions from the previous discussion of Potential Energy Benefits, 500 thread forming fasteners per vehicle

16 million vehicles per year built in North America

Average operating cost savings of $\$ 0.08$ per thread forming fastener implemented The total annual economic benefit would equal $\$ 640$ million per year for North American automobile manufacturing alone.

There will be a direct reduction in greenhouse gas emissions as a result of the energy saved in the elimination of machining as described in the previous section. The assumption is that all the energy identified is electricity, though reduction in floor space would impact natural gas usage as well. According to DOE-OIT energy savings worksheets, the production of electricity results in carbon dioxide emission rates of 0.019 million tons of carbon equivalent per trillion Btu. The work sheets also indicate the production of electricity results in the following greenhouse gas emission rates in lb./MMBtu:

\begin{tabular}{|c|c|c|c|c|c|c|}
\hline VOC & NOX & CO & SO2 & PM10 & PM25 & Other \\
\hline 0.004409 & 0.377305 & 0.041573 & 0.617609 & 0.013228 & 0.008225 & 0.006 \\
\hline
\end{tabular}

When the technology is fully implemented and at least 5 trillion BTU of electrical energy savings is achieved annually, at least 190 million pounds of carbon equivalent will be eliminated.

Greenhouse gas emissions reduction will be in thousands of pounds annually:

\begin{tabular}{|c|c|c|c|c|c|c|}
\hline VOC & NOX & CO & SO2 & PM10 & PM25 & Other \\
\hline 22 & 1887 & 208 & 3088 & 66 & 41 & 30 \\
\hline
\end{tabular}

In addition to the greenhouse emission improvements, further environmental improvements, though not numerically estimated, will result from elimination of machining coolant and machining chips for recycling. 


\subsection{Non-Automotive Applications}

Many markets outside the North American automotive industry will be similarly impacted by this technology. Thread forming fasteners will have similar benefits to any industry that uses aluminum or magnesium castings and drills and taps to accommodate attachments. Those industries include heavy trucks, farm equipment, military, marine, heavy construction equipment, gardening equipment, recreational vehicles, and aero/space. Certain major appliances like washers and dryers could be impacted as well.

\begin{tabular}{|c|c|c|c|c|c|c|}
\hline \multicolumn{7}{|c|}{ Potential non-Automotive Applications of Thread Forming Fasteners } \\
\hline \multirow{4}{*}{ Commodity } & & & $50 \%$ & Total & Annual & Annual \\
\hline & Annual & Fasteners & Replaced & Annual & Energy & Economic \\
\hline & $\underline{\text { Volume }}$ & per Unit & by TFF's & $\underline{\text { TFF's }}$ & Savings & Savings \\
\hline & (Million Units) & & & (Million Fasteners) & (Trillion btu) & (\$ Million) \\
\hline Heavy truck \& Const. & 2 & 400 & 200 & 400 & 0.216 & 32 \\
\hline Motorcycles & 1.1 & 100 & 50 & 55 & 0.0297 & 4.4 \\
\hline Home Appliances & 15 & 30 & 15 & 225 & 0.1215 & 18 \\
\hline Kitchen/Shop Tools & 15 & 10 & 5 & 75 & 0.0405 & 6 \\
\hline Garden Appliances & 5 & 30 & 15 & 75 & 0.0405 & 6 \\
\hline Farm Equipment & 1 & 300 & 150 & 150 & 0.081 & 12 \\
\hline Aerospace & 0.25 & 1000 & 500 & 125 & 0.0675 & 10 \\
\hline Marine & 1 & 400 & 200 & 200 & 0.108 & 16 \\
\hline Recreational Vehicles & 0.1 & 400 & 200 & 20 & 0.0108 & 1.6 \\
\hline Stationary Equipment & 1 & 200 & 100 & 100 & 0.054 & 8 \\
\hline Military & & & & & 0.27 & 40 \\
\hline Military & & & & 500 & 0.27 & 40 \\
\hline & & & & & & \\
\hline TOTAL & & & & 1925 & 1.0395 & 154 \\
\hline & & & & & & \\
\hline
\end{tabular}

Table 9.1 Estimated Energy and Economic benefits for Non-Automotive Applications

Sources for several of these estimates are listed in the References section of this document. 


\subsection{Overall Benefit}

The overall benefit of this technology is a combination of automotive and nonautomotive applications. Therefore the combined energy savings is estimated to exceed 6 trillion btu annually at full implementation ( 5 trillion automotive and 1 trillion non-automotive). The combined annual economic benefit is estimated at nearly $\$ 800$ million. 


\subsection{Commercialization}

The data generated in this project will lead directly to the elimination of a significant barrier to wide usage of this technology.

The technology is completely commercialized but not widely used due to the lack of experience and lack of the data provided by this study. Implementation of the technology will be accelerated by the involvement of the fastener manufacturers, the fastener thread form designers and the industrial association, Industrial Fasteners Institute (IFI). In addition, this report will be made available to the North American Die Casting Association (NADCA), and American Foundry Society (AFS).

The technical specialists for fasteners within the USCAR companies were part of the team performing this work and will carry this knowledge into the companies to invigorate the wide spread implementation. 


\subsection{Accomplishments}

\section{Task 1.0: Potential Benefits Assessment}

The initial Potential Benefits Assessment was completed during the first quarter. The assessment was updated during the most recent quarter and adjusted for new information. Overall, Task 1, when completed, indicated strong economic, energy and environmental benefits with the proliferation of thread forming fasteners throughout the automobile and other heavy manufacturing industries.

\section{Task 2.0: Determine Clamp Load Range for Taptite Fasteners in A380 Aluminum}

This task was designed to determine the full range of clamp load values over the full range of variance in hole shapes and sizes normally experienced by a high pressure die casting die during normal duty cycle. The work was originally conceived with a hired technician to perform the actual bolt tightening experiments. Ford volunteered to perform the experiments, so a cost savings was realized and a cost share increased. The work was completed as designed and the results were favorable.

\section{Task 3.0: Determine Clamp Load Range for ALtracs Fasteners in AZ91D Magnesium}

This task was a duplicate of Task 2, but with ALtracs fasteners in AZ91D magnesium alloy as-cast holes. Similar cost savings were achieved with Ford performing the testing. As in task 2, the work was completed as designed and the results were favorable.

\section{Task 4.0: Project Management and Reporting}

All project management and reporting procedures were established to meet DOE and USCAR requirements. The project was delayed due to a key technical consultant undergoing surgery with a long recovery. However, all reporting requirements were achieved within the adjusted timing.

No publications or presentations resulted from this work. However, the Final Technical report will be offered to the Industrial Fasteners Institute (IFI), the North American Die Casting Association (NADCA), and the American Foundry Society (AFS) for distribution to their memberships. 


\subsection{Conclusions}

The fully implemented potential benefit of thread forming fasteners in as-cast holes of aluminum and magnesium is estimated to be 6 trillion btu per year for North America across all industries. Economic benefit is estimated to be nearly $\$ 800$ million per year. Environmental benefits and quality improvements will also result from full implementation of this technology. The major hurdle to implementation is lack of confidence in achieving desired clamp load.

The primary issues at the source of engineers' reluctance to implementing thread forming fasteners in lightweight castings are:

- Little proof of consistency of clamp load vs. input torque

- No known data to understand the effect on consistency of clamp load as casting dies wear.

The clamp load data gathered in this project represented the severity of clamp load variation in as-cast holes. This range of variation was compared to clamp load variation from traditional bolts and nuts. The results of this work showed that clamp load variation with thread forming fasteners is consistent with industry expectations for standard steel bolts and nuts at $+/-30 \%$. There does not appear to be any significant increase in clamp load variation due to the application of thread forming fasteners in as-cast holes of aluminum or magnesium over the effective life of a die casting mold.

Particularly encouraging was the outcome of the robustness tests. Even with cast holes $.05 \mathrm{~mm}$ larger and smaller than the expected hole size variation, the clamp load range remained within the industry expectation of $+/-30 \%$.

The remaining hurdles to confident and wide implementation of this technology appear to be experience and design constraints.

- Products will need to be designed to assure proper length of thread engagement. With as -cast holes, there is a draft angle involved, so depth of thread engagement is critical to achieving desired clamp load and mode of failure. In products where depth of engagement cannot be maintained, thread forming fasteners may not be a good fit.

- Casting processes and quality operating systems will need to be adjusted to provide assurance that all core pins are properly monitored and maintained. Repair and recovery procedures will need to be prepared.

These remaining hurdles can be overcome with thoughtful product and process design. 


\subsection{Recommendations}

This report will be distributed to the domestic automobile companies as well as the associated supply base. In addition, the report will be distributed to the fastener and casting industry associations. It will be recommended to these organizations that this information be further distributed. In addition, recipients of the report should be encouraged to apply this technology to gain experience and confidence. 


\subsection{References}

"Die Cast Net-Shaped Hole Process Development", D. M. Paxton, W. A. Charron, T. H. Cleaver, USAMP/DOE Project AMD 407 Final Report, September 2006

"Real-Time Ultrasonic Control of Bolt Tightening for Automotive Plants: Development Phase", M.S. Good, B.E. Watson, M.A. Hughes, K.C. Roberts, A.P. Cockman, M. Nasro, T.H. Cleaver, R. Cleaver, USCAR Project JNG 601 Final Report, May 2011

NMMA's (National Marine Manufacturers Association) 2009 Recreational Boating Statistical Abstract

"Motorcycle Sales Down 40.8\% Says MIC", Bart Madson, Motorcycle USA.com, January 21,2010

"North American Commercial Truck \& Trailer Outlook, Equipment, Freight, Trucking, Economics", FTR Associates, September, 2008 


\subsection{Appendices}

\subsection{Team Members}

Adrian Cockman

Ford Motor Company

Richard Talbott

Ford Motor Company

William Charron

Ford Motor Company

Gary Sifferman

Acument Global Technologies

Joe Gobernatz

ATF

John Reynolds

REMINC

Ryan Cleaver

Tech Knowledge

Todd Cleaver

Tech Knowledge 


\subsection{Size \& Shape Hole Dimensions for TAPTITES in Aluminum}

June 14, 2011

The die for the nut plate is engraved on the boss surface as indicated in the dotted boxes. The letters are located so they remain with the nut after machining to the $20 \mathrm{~mm}$ square required for clamp load testing.

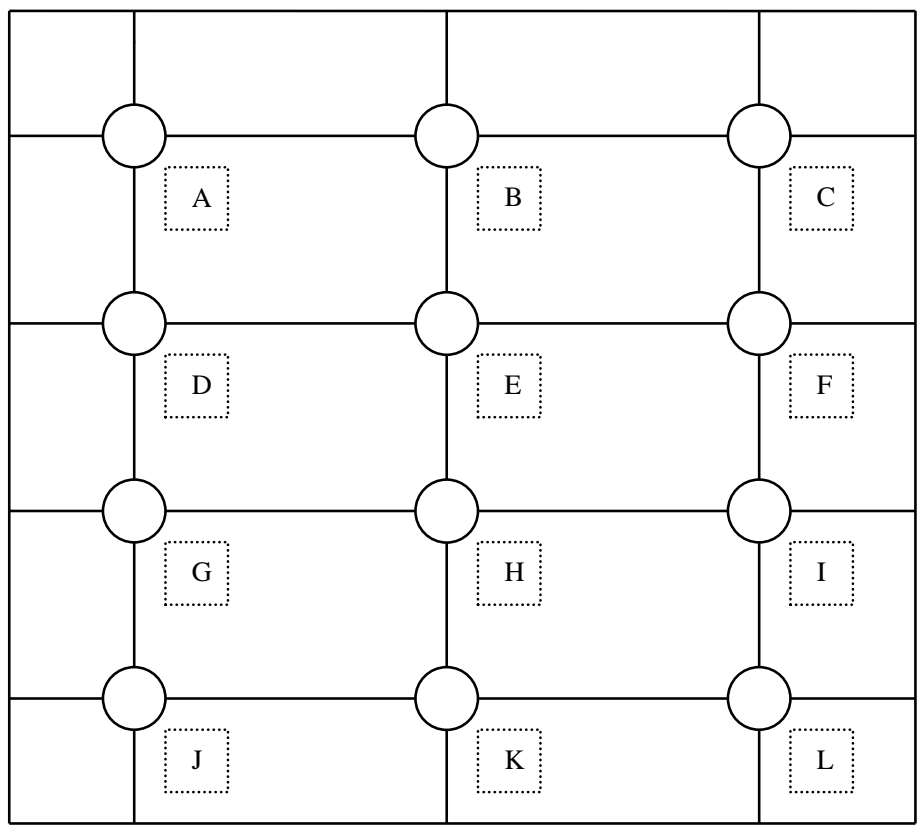

Fig. 15.1 Boss Designations for Cast Nuts in Aluminum 
Size \& Shape Hole Dimensions for TAPTITES in Aluminum June 14, 2011

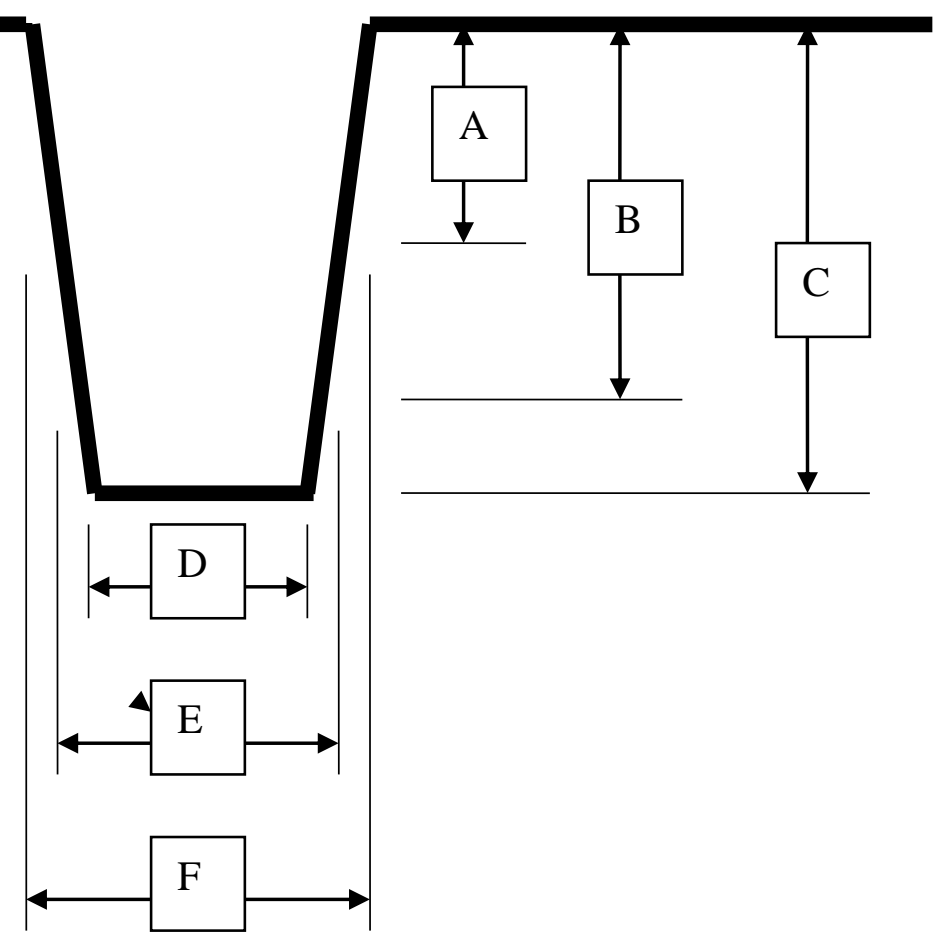

Dimension $\mathrm{D}$ is the diameter at depth $\mathrm{C}$.

Dimension $\mathrm{E}$ is the diameter at depth $\mathrm{B}$.

Dimension $\mathrm{F}$ is the diameter at depth $\mathrm{A}$.

\begin{tabular}{|c|c|c|c|c|c|c|c|c|}
\hline & & \multicolumn{6}{|c|}{ Hole Dimension in $\mathrm{mm}$} & Draft \\
\hline Pin ID & Pin Description & $\mathbf{A}$ & B & $\mathbf{C}$ & $\mathbf{D}$ & $\mathbf{E}$ & $\mathbf{F}$ & Angle \\
\hline$\overline{\bar{A}}$ & 2.5 Dia. Depth, .5 Degree, nominal & & 15 & 19 & & 5.44 & & $.5 \mathrm{Deg}$ \\
\hline B & 2.5 Dia. Depth, .5 Degree, nom. +.05 & & 15 & 19 & & 5.49 & & $.5 \mathrm{Deg}$ \\
\hline C & 2.5 Dia. Depth, .5 Degree, nom +.10 & & 15 & 19 & & 5.54 & & $.5 \mathrm{Deg}$ \\
\hline $\mathrm{D}$ & 2.5 Dia. Depth, .5 Degree, nom. - .05 & & 15 & 19 & & 5.39 & & $.5 \mathrm{Deg}$ \\
\hline$E$ & 2.5 Dia. Depth, .5 Degree, nom. - .10 & & 15 & 19 & & 5.34 & & $.5 \mathrm{Deg}$ \\
\hline $\mathrm{F}$ & 2.5 Dia. Depth, .5 Degree, nom. - .15 & & 15 & 19 & & 5.29 & & $.5 \mathrm{Deg}$ \\
\hline$G$ & 2.5 Dia. Depth, 1.0 Degree, nominal & & 15 & 19 & & 5.44 & & $1.0 \mathrm{Deg}$ \\
\hline $\mathrm{H}$ & 2.5 Dia. Depth, 1.0 Degree, nom. + .05 & & 15 & 19 & & 5.49 & & $1.0 \mathrm{Deg}$ \\
\hline I & 2.5 Dia. Depth, 1.0 Degree, nom. - .05 & & 15 & 19 & & 5.39 & & $1.0 \mathrm{Deg}$ \\
\hline $\mathrm{J}$ & 2.5 Dia. Depth, 1.0 Degree, nom. - .10 & & 15 & 19 & & 5.34 & & $1.0 \mathrm{Deg}$ \\
\hline $\mathrm{K}$ & 2.5 Dia. Depth, 1.0 Degree, nom. - .15 & & 15 & 19 & & 5.29 & & $1.0 \mathrm{Deg}$ \\
\hline $\mathrm{L}$ & 2.5 Dia. Depth, .5 Degree, nominal & & 15 & 19 & & 5.44 & & $.5 \mathrm{Deg}$ \\
\hline
\end{tabular}

Table 15.1 Hole Dimensions and Draft Angles for Cast Nuts in Aluminum 


\subsection{Size \& Shape Hole Dimensions for ALtracs in Magnesium}

June 14, 2011

The die for the nut plate is engraved on the boss surface as indicated in the dotted boxes. The letters are located so they remain with the nut after machining to the $20 \mathrm{~mm}$ square required for clamp load testing.

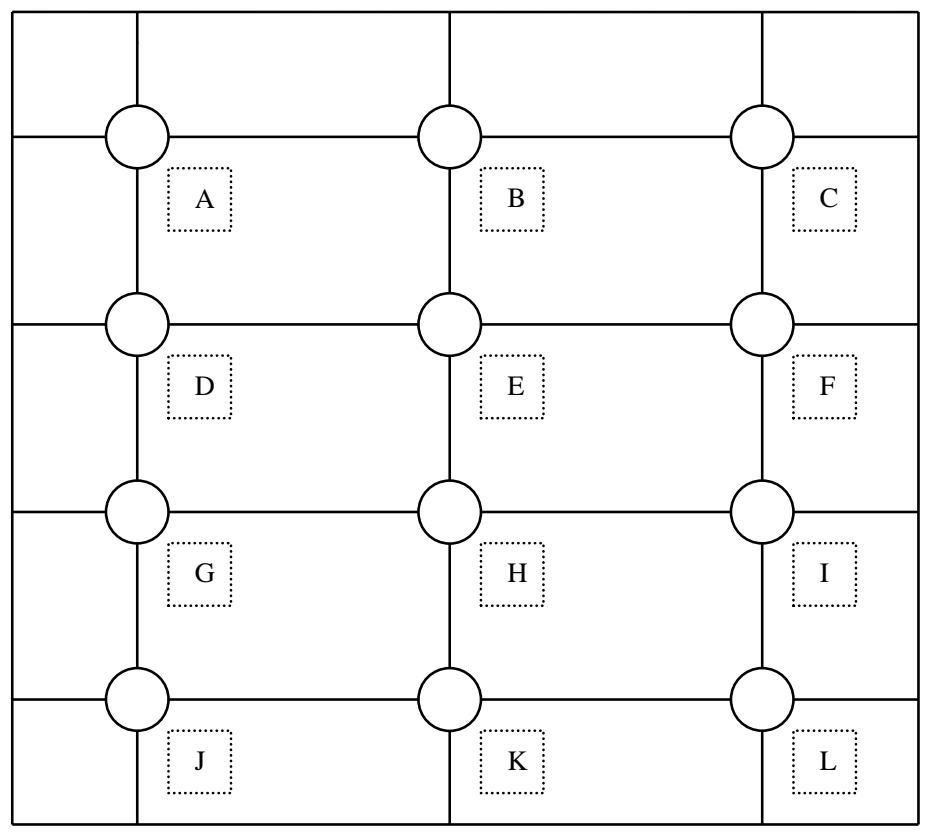

Fig. 15.2 Boss Designations for Cast Nuts in Magnesium 


\section{Size \& Shape Hole Dimensions for ALtracs in Magnesium}

June 14, 2011

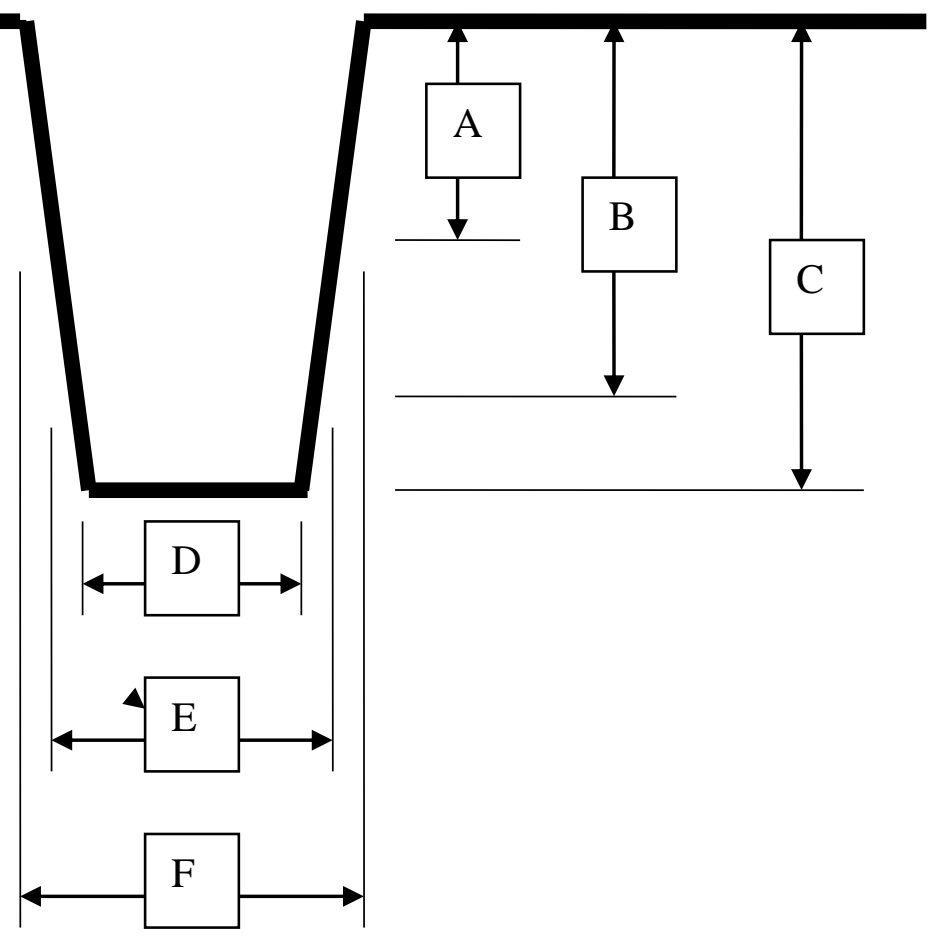

Dimension $\mathrm{D}$ is the diameter at depth $\mathrm{C}$.

Dimension $\mathrm{E}$ is the diameter at depth $\mathrm{B}$. Dimension $\mathrm{F}$ is the diameter at depth $\mathrm{A}$.

\begin{tabular}{|c|c|c|c|c|c|c|c|c|}
\hline & & \multicolumn{6}{|c|}{ Hole Dimension in $\mathrm{mm}$} & Draft \\
\hline Pin ID & Pin Description & A & B & $\mathrm{C}$ & D & $\bar{E}$ & $\mathbf{F}$ & Angle \\
\hline$A$ & 3 Dia. Depth, .5 Degree, nominal & 9 & & 22 & & & 5.65 & $.5 \mathrm{Deg}$ \\
\hline $\mathrm{B}$ & 3 Dia. Depth, .5 Degree, nom. +.05 & 9 & & 22 & & & 5.70 & $.5 \mathrm{Deg}$ \\
\hline C & 3 Dia. Depth, .5 Degree, nom. +.10 & 9 & & 22 & & & 5.75 & $.5 \mathrm{Deg}$ \\
\hline $\mathrm{D}$ & 3 Dia. Depth, .5 Degree, nom. - .05 & 9 & & 22 & & & 5.60 & $.5 \mathrm{Deg}$ \\
\hline $\mathrm{E}$ & 3 Dia. Depth, .5 Degree, nom. - .10 & 9 & & 22 & & & 5.55 & $.5 \mathrm{Deg}$ \\
\hline $\mathrm{F}$ & 3 Dia. Depth, .5 Degree, nom. - .15 & 9 & & 22 & & & 5.50 & $.5 \mathrm{Deg}$ \\
\hline$G$ & 3 Dia. Depth, 1.0 Degree, nominal & 9 & & 22 & & & 5.65 & $1.0 \mathrm{Deg}$ \\
\hline $\mathrm{H}$ & 3 Dia. Depth, 1.0 Degree, nom. +.05 & 9 & & 22 & & & 5.70 & $1.0 \mathrm{Deg}$ \\
\hline I & 3 Dia. Depth, 1.0 Degree, nom. - .05 & 9 & & 22 & & & 5.60 & $1.0 \mathrm{Deg}$ \\
\hline $\mathrm{J}$ & 3 Dia. Depth, 1.0 Degree, nom. - .10 & 9 & & 22 & & & 5.55 & $1.0 \mathrm{Deg}$ \\
\hline $\mathrm{K}$ & 3 Dia. Depth, 1.0 Degree, nom. - .15 & 9 & & 22 & & & 5.50 & $1.0 \mathrm{Deg}$ \\
\hline $\mathrm{L}$ & 3 Dia. Depth, .5 Degree, nominal & 9 & & 22 & & & 5.65 & $.5 \mathrm{Deg}$ \\
\hline
\end{tabular}

Table 15.2 Hole Dimensions and Draft Angles for Cast Nuts in Magnesium 


\subsection{Cross-Section Metallographic Samples}

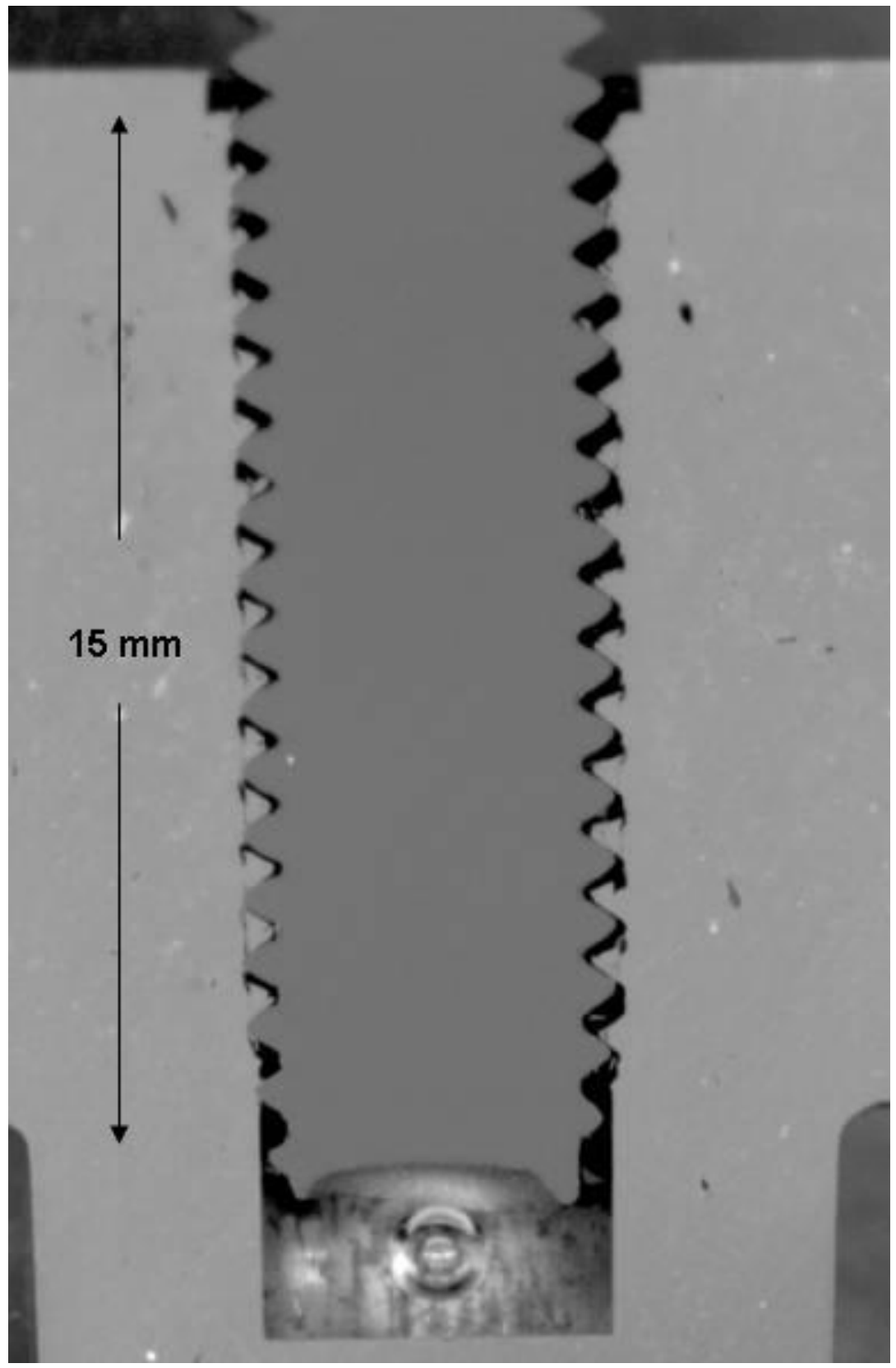

Fig. 15.3 Cross-Section Metallographic Sample of M6 Taptite Thread Forming Fastener at $15 \mathrm{~mm}$ Depth in $0.5^{\circ}$ Draft Angle As-Cast Hole in A380 Aluminum 


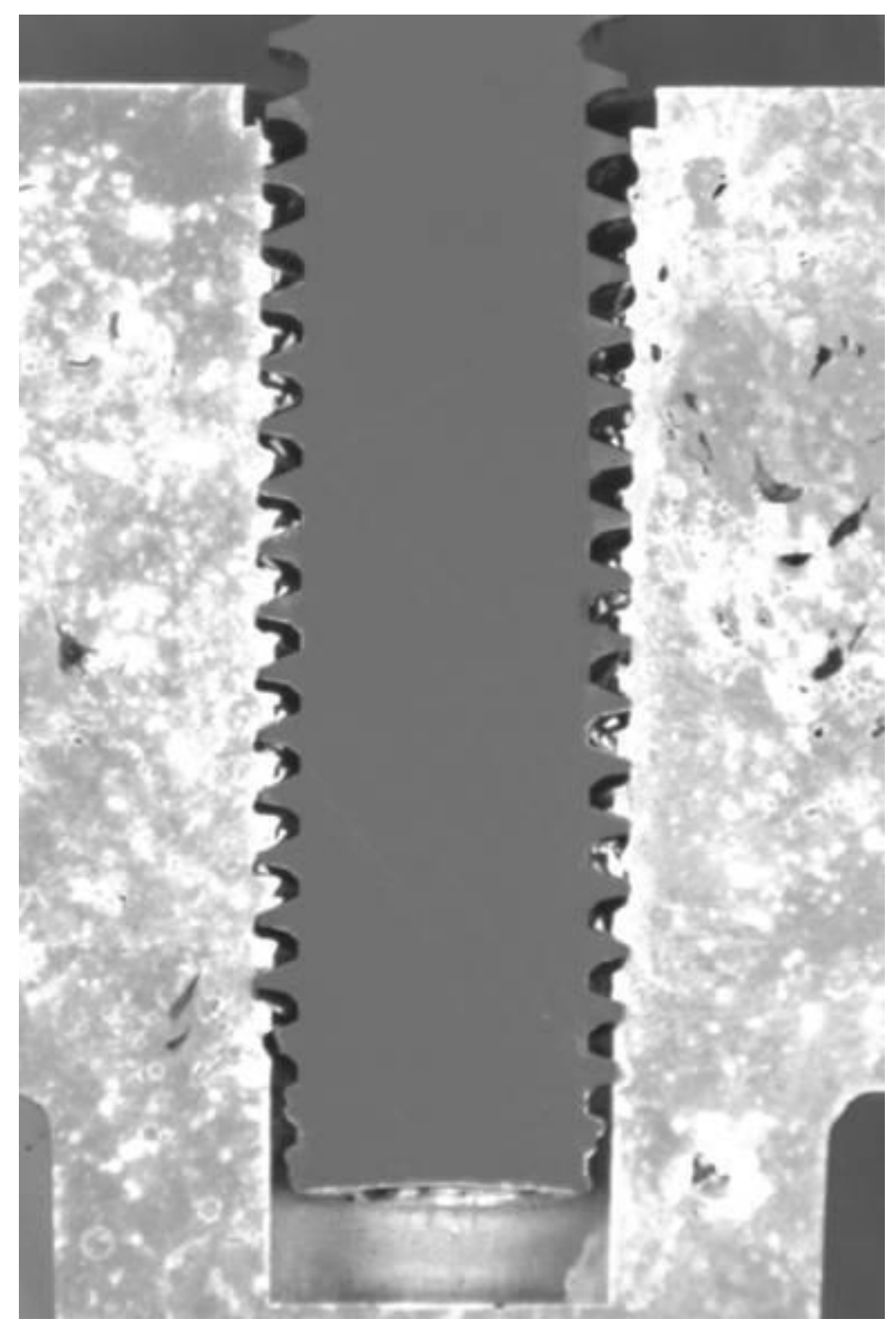

Fig. 15.4 Cross-Section Metallographic Sample of M6 ALtracs Thread Forming Fastener at $18 \mathrm{~mm}$ Depth in 0.5을 Draft Angle As-Cast Hole in AZ91D Magnesium 